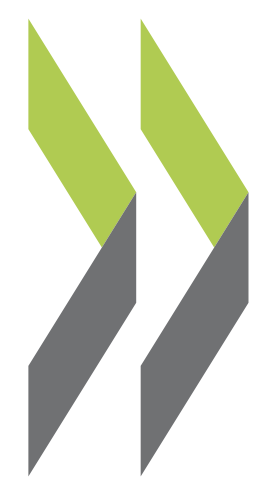

OECD Economics Department Working Papers No. 852

Enhancing Labour Utilisation in a Socially Inclusive Society in Australia

Vassiliki Koutsogeorgopoulou 
Organisation de Coopération et de Développement Économiques

Organisation for Economic Co-operation and Development

01-Apr-2011

ECONOMICS DEPARTMENT

English - Or. English

ENHANCING LABOUR UTILISATION IN A SOCIALLY INCLUSIVE SOCIETY IN AUSTRALIA

ECONOMICS DEPARTMENT WORKING PAPERS No. 852

by Vassiliki Koutsogeorgopoulou

All Economics Department Working Papers are available through OECD's Internet website at http://www.oecd.org/eco/Workingpapers 


\section{ABSTRACT/RÉSUMÉ}

\section{Enhancing labour utilisation in a socially inclusive society in Australia}

Australia faces the mutually reinforced challenges of boosting labour supply and promoting social inclusion. Labour underutilisation is especially prevalent among groups such as lone parents, people with disability, and Indigenous Australians. These are also groups at greatest risk of social exclusion. Thus better integration of these groups into the labour market would enhance inclusion. In general, labour utilisation can be increased by training, improving the functioning of labour market institutions, reforming the tax and transfer system, and maintaining labour market flexibility. Beyond labour market policies, the multiplicity, inter-relatedness and complexity of social inclusion problems call for a comprehensive and integrated approach focusing on individual needs. The elements of the strategy include an education system that better promotes equity and integrated service approaches to help people with disabilities and the homeless. Recent efforts in all these areas by the government are welcome.

Keywords: social inclusion; exclusion; well-being; underutilisation of labour; tax-transfer system; labour market; flexibility; immigration; education; disability; homelessness.

JEL classification: I30; I38; J08; J21; J24; J61

This Working Paper relates to the 2010 OECD Economic Survey of Australia (www.oecd.org/eco/surveys/Australia).

*******************************************************

\section{Optimiser l'utilisation de la main-d'œuvre tout en favorisant l'inclusion sociale en Australie}

L'Australie doit relever un double défi : augmenter l'offre de main-d'œuvre tout en œuvrant en faveur de l'inclusion sociale. La sous-utilisation de la main-d'œuvre touche plus particulièrement les catégories de population vulnérables, comme les parents isolés, les personnes handicapées et les Australiens autochtones, qui sont également les plus exposées au risque d'exclusion sociale. Une meilleure insertion de ces populations sur le marché du travail aurait donc une incidence positive sur l'inclusion sociale. D'une manière générale, les formations, l'amélioration des institutions du marché du travail, la réforme du système d'impôts et de prestations et le maintien de la flexibilité du marché du travail peuvent renforcer l'utilisation de la main-d'œuvre. Au-delà des politiques du marché du travail, les multiples aspects de l'exclusion sociale, leur complexité et leurs interrelations appellent une approche globale et intégrée, axée sur les besoins individuels. La stratégie adoptée repose notamment sur une réforme du système éducatif afin de garantir l'égalité des chances à l'école, ainsi que sur des systèmes de services intégrés pour venir en aide aux handicapés et aux sans-abri. Il faut donc saluer les efforts consentis récemment dans ce sens par les pouvoirs publics australiens.

Mots clés : inclusion sociale; exclusion; bien-être; sous-utilisation du travail ; système d'impôts et de prestations ; marché du travail ; flexibilité; immigration ; éducation ; invalidité; problème des sans-abri.

Classification JEL : I30 ; I38 ; J08 ; J21; J24; J61

Ce Document de travail se rapport à l'Étude économique de l'OCDE de l'Australie

(www.oecd.org/eco/etudes/Australie).

Copyright OECD, 2011

Application for permission to reproduce or translate all, or part of, this material should be made to: Head of Publications Service, OECD, 2 rue André Pascal, 75775 Paris Cedex 16, France. 


\section{TABLE OF CONTENTS}

Enhancing labour utilisation in a socially inclusive society in Australia ............................................5

Underutilisation of labour and social exclusion are closely linked in Australia .........................................7

There is a large pool of underutilised workers ..................................................................................

Multiple disadvantages lead to social exclusion and weaker labour market outcomes..........................11

Addressing Australia's future employment needs and social challenges .............................................14

The tax-transfer systems need to strike a balance between poverty and incentives to work for

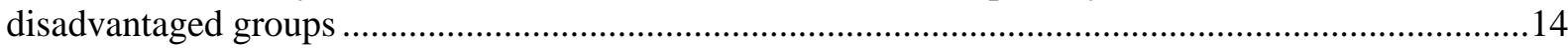

Employment is affected by access to affordable high quality child care services ...............................17

Reforms in the transfer system and childcare services should boost labour force participation .............18

Labour market institutions should remain flexible ..........................................................................22

Better education and training can reduce educational disadvantages for disadvantaged groups and

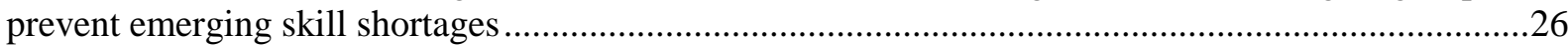

Social inclusion calls for comprehensive service delivery .................................................................33

Improving the governance of policy actions is important for effective results ......................................37

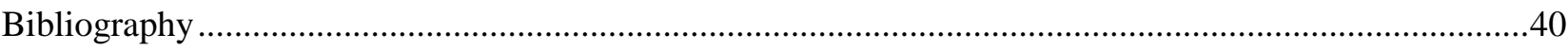

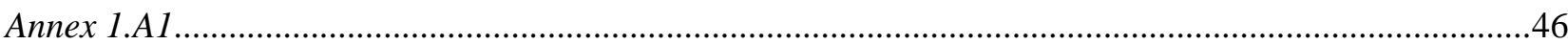

\section{Tables}

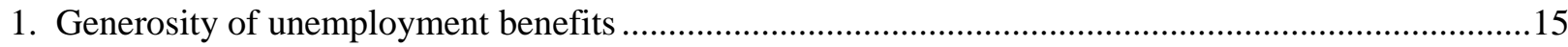

1.A1.1 Ordered probit regression of life satisfaction on different components, controlling for individual-

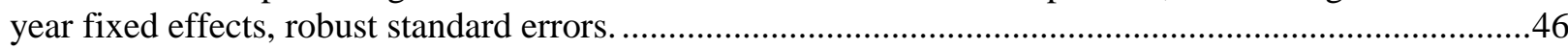

\section{Figures}

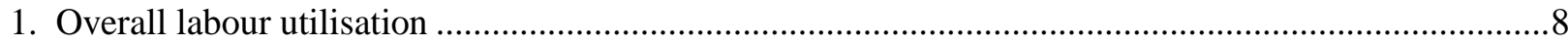

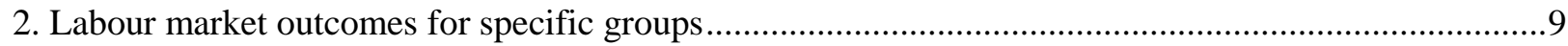

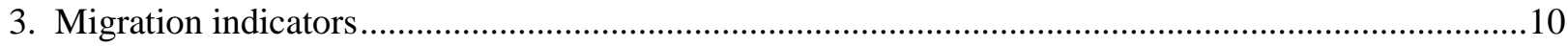

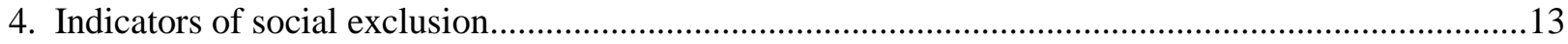

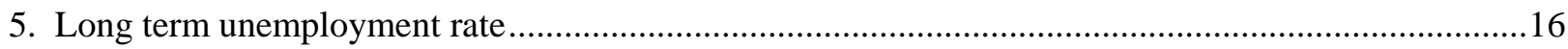

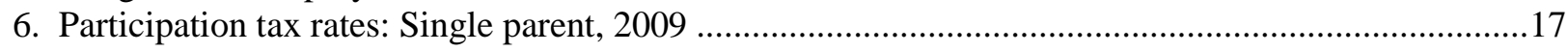

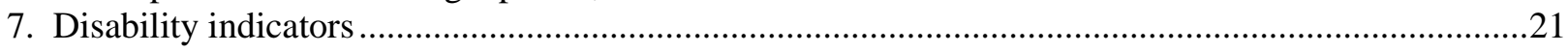

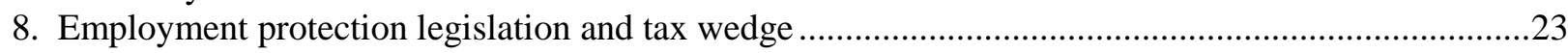

9. Minimum wages and in-work poverty: an international comparison ................................................24

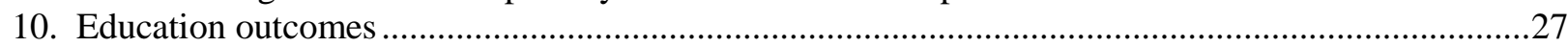

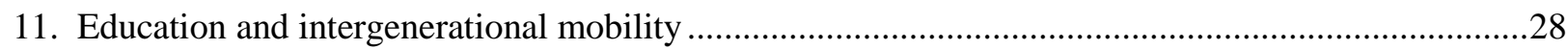




\section{Boxes}

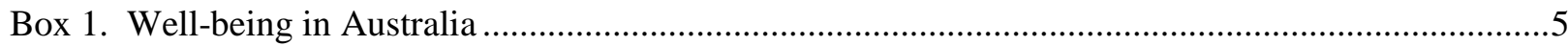

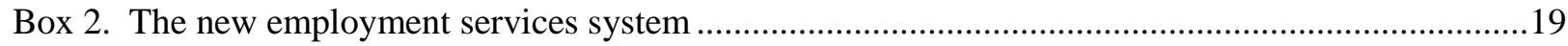

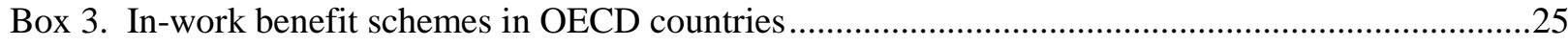

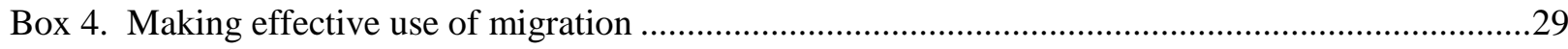

Box 5. Recent measures to address education challenges.....................................................................

Box 6. Policy initiatives to promote employment and social outcomes for people with disabilities.........34

Box 7. Increasing labour supply while addressing social inclusion........................................................38 
ECO/WKP(2011)21

\title{
Enhancing labour utilisation in a socially inclusive society in Australia
}

\author{
By Vassiliki Koutsogeorgopoulou ${ }^{1}$
}

Boosting labour supply and maintaining flexible labour markets are among the key economic challenges in dealing with structural changes. Skill and labour shortages were already emerging prior to the global financial crisis, and are likely to intensify going forward given the subsequent resilience of the labour market and expected rise in labour demand over time. Raising labour supply would also help in tackling social exclusion, which is an important aspect of well-being in Australia (Box 1). A more inclusive society would enable a broader sharing of the benefits of economic prosperity, and contribute to it. While Australia fares well in cross-country comparisons of many indicators related to social inclusion, there is scope for better outcomes for some groups, such as lone parents, people with disability and Indigenous populations. Future policy improvements in this area will also need to ensure the long-term sustainability of the government's finances.

A lack of access to the job market is an important, but not the only, driver of social exclusion. Other dimensions include poverty, low educational qualifications, poor health, homelessness and weak participation in society. The government has sought to increase social inclusion through a systematic and integrated approach (Australian Government 2010a). Being socially included is defined as having the resources (skills and assets), opportunities and capabilities necessary to learn, work (paid or unpaid), engage in society and have a voice.

\section{Box 1. Well-being in Australia}

GDP as a measure of well-being has well known drawbacks, most recently highlighted by Stiglitz et al. (2009). GDP reflects annual market production in a country, while many monetary and non-monetary factors (wealth, own production or leisure, health, environment, social inclusion) also affect well-being, and some production (household services or the decline in natural resources, for example) is not captured by market transactions. In recent years, a large body of theoretical and empirical research has examined the inherently complex conceptual and measurement problems related to a broader concept of well-being. Research has been facilitated by international efforts to develop comparable well-being indicators (World Value Survey, Gallup World Poll). ${ }^{1}$ Stiglitz et al. (2009) emphasise that well-being is a multi-dimensional concept, and identify, in addition to material living standards, health, education, personal activities, political voice and governance, social connections and relationships, environment and economic and physical insecurity as important determinants of well-being. Other studies show that well-being is not just a function of income at a point in time, but adapts to changes in income over time. If GDP growth slows when living standards are high, life satisfaction can decrease (Di Tella et al., 2003).

1. This paper was originally produced for the 2010 OECD Economic Survey of Australia, published in November 2010 under the authority of the Economic and Development Review Committee of the OECD. I would like to thanks, without implicating, Andrew Dean, Piritta Sorsa, Claude Giorno, colleagues in the Directorates of Education and of Employment and Labour and Social Affairs, and the Australian government officials for valuable comments and/or discussions. Special thanks to Sarah Flèche for the preparation of the Box on well-being included in the paper. I am also grateful to Josette Rabesona and Ane Kathrine Christensen for technical assistance and to Deirdre Claassen for secretarial assistance. 
Policy makers are increasingly interested in these additional indicators and their determinants as complements to GDP; for example an index of well-being has been developed in Canada. Efforts to improve the measurement of well-being are being coordinated in an ongoing OECD project on "Measuring Progress in Societies". In this context the Australian government has articulated the goal of improving the well-being of current and future generations, and recognizes that well-being is a multi-dimensional concept that goes beyond GDP per capita and economic performance, and that policies should take into account the stock of environmental, human and social resources (Australian Government, 2010b). The Australian Bureau of Statistics has published a dashboard of well-being indicators since 2002, in line with Stiglitz et al., (2009).

Comparing well-being across countries and over time remains a challenge and there are many ways to measure it. The types of measures include expanded GDP, weighted averages of life satisfaction indexes, and self-reported subjective assessments of well-being based on survey data (Boarini et al., 2006). Self-reported subjective well-being can be further divided into life satisfaction surveys (ranks of 0 to 10 of a person's satisfaction with life) and emotional well-being indicators (a person's emotional feelings about life today) (Kahneman and Deaton, 2010). Index-based measures face problems with subjective weights, while expanded GDP excludes potentially important factors of well-being. Studies based on self-reported life satisfaction avoid these problems, but are subject to challenging data interpretation issues. These studies, which are getting increasing attention in the literature (Helliwell et al., 2009 and 2010), tend to show that self-reported subjective well-being has a strong correlation with income, but also that other factors, such as social context based on opportunities and capabilities, play an important role.

For Australia, which is characterized by high incomes and strong GDP growth over the past decade, self-reported life satisfaction is above the OECD average with Australia ranked eleventh within the OECD in 2008, below many Nordic countries and some other Anglo-Saxon economies (Gallup World Poll). Moreover, life satisfaction seems to have slightly declined in the past years, whereas it remained broadly stable on average in the OECD. ${ }^{2}$

To better understand self-reported well-being relationships in Australia in comparison with other OECD countries, ${ }^{3}$ some tentative and exploratory analysis was done (Fleche et al., 2011). Ordered probit and weighted-least-squares regressions of well-being (life satisfaction), were estimated for various explanatory variables, using data from the World Values Survey (1981-2007) (see Annex 1.A1). The explanatory power of each covariate/determinant of life satisfaction can be compared with (the log of) income, to shed some light on the relative importance of various well-being dimensions to life satisfaction. However, this method cannot explain well-being developments over time nor demonstrate causality.

According to this analysis, in Australia the most important factors for self-reported subjective well-being, apart from income, are (self-evaluated) health, social cohesion, personal activities and unemployment (Table 1.A1.1). As in other OECD countries, the importance of health seems high relative to other well-being determinants. Being unemployed strongly decreases life satisfaction, which is in line with similar studies in other countries (Winkelmann and Winkelmann, 1998). Subjective measures of social trust, freedom of choice and control of personal activities also have statistically significant links with the self reported well-being of Australians.

Among other factors, having a higher educational level does not have a major direct impact on life satisfaction, but would have indirect benefits by improving access to employment, contributing to higher productivity, and enhancing the opportunity to participate in economic and social activities. Perceived income inequality decreases life satisfaction. Concern about the state of the current and future environment (for example, as proxied by $\mathrm{CO}_{2}$ emissions from fuel combustion) has a higher coefficient in Australia than in the average of OECD countries, although it is low in Australia compared to other determinants of well-being. Finally, reported interest in politics increases life satisfaction in Australia, while indicators of perceived political corruption, as well as divorce, decrease life satisfaction. These empirical exploratory results confirm the multidimensional nature of well-being in Australia.

1. The Gallup World Poll and the World Values Survey provide measures like "life satisfaction". Life satisfaction is defined from the following question "all things considered, how satisfied are you with life as whole these days?" the answer is on 0 to 10 numerical scale. The top of the ladder (10) represents the best possible life and the bottom of the ladder (0) represents the worst possible. However, these surveys are not official statistical sources and provide relatively small samples. (1660 observations for Australia, 14410 for the OECD).

2. For Australia, there are only data for 1981, 1995, 2005 and 2008. According to Gallup World Poll, self-reported life satisfaction slightly declined in Australia between 2005 and 2008. The World Value Survey also points to some weakening in well-being between 1981 and 2005.

3. To compare the results for Australia to those of the OECD on average, a statistical test was run to determine the significance of the difference between the coefficients. While this is not significantly different from zero at $5 \%$ level of significance, it, however, suggests that the size of the determinants of well-being estimated in the regressions is meaningfully similar on the average in the other OECD countries. 


\section{Underutilisation of labour and social exclusion are closely linked in Australia}

\section{There is a large pool of underutilised workers}

Despite high overall labour force participation rates (Figure 1, Panel A), labour in Australia is underutilised more than average in the OECD (Figure 1, Panel C). Underutilisation includes the unemployed, the underemployed (workers who would like to work more hours) and workers who are marginally attached to the labour force. Part of the underemployment is cyclical, as adjustment during the recent downturn involved a reduction in working hours, but it was already high before the slowdown. Some of the groups involved people with disabilities, lone parents and Indigenous Australians face particularly weak labour market engagement, which raises the risk of social exclusion. The most important underutilised groups are:

- Women, especially those with families. Although female participation rates have increased markedly over the past decades, they lag behind male rates and the OECD best performers (Figure 1, Panel B). Women with dependent children, especially very young ones, have particularly low employment rates (Figure 2, Panel A). The effective labour supply of all female workers is even lower due to extensive part-time work (Figure 2, Panel B). Around a quarter of part-timers in September 2009 wanted to work extra hours, although only about half of these part-timers wanting more hours were actively seeking more hours (ABS, 2010a).

- Lone parents. About a fifth of families with children are headed by lone parents, and Australia has one of the lowest employment rates for single parents in the OECD (Figure 2, Panel C). While employment rates have increased over time, a sizeable gap remains compared to two parent families, especially for those with young children (Figure 2, Panel D). Indeed, approximately $60 \%$ of jobless families are headed by lone parents (Vinson, 2009).

- People with disabilities. The employment outcomes of people with disability are poor, even by international comparisons (Figure 2, Panel E), and those with mental illness fare worse than the physically disabled (Australian Government 2010a). Labour market integration of all those people with disability wishing to work could boost labour supply by as much as 5 percentage points by 2050, according to OECD estimates, depending on the degree of activation of this group (OECD, 2007a).

- Older workers, especially those with disabilities. The participation rate of older (55 to 64 years of age) workers ranks above OECD average, but falls below best performing countries. Exit from the labour force is particularly marked among those at 55, which can reflect incentives in the taxtransfer system to apply for Disability Support Pensions (DSP), retirement arrangements, ${ }^{2}$ lack of suitable jobs, and limited retraining opportunities (Figure 2, panel F). Disability pension rates are highest among older workers (over 55), as in other OECD countries (OECD, 2009a).

- Low educational attainment. Participation rises markedly with the level of education (Figure 2, Panel G), and low educational attainment is also associated with higher unemployment and underemployment. More than $60 \%$ of involuntary part-time workers have no post-secondary school qualifications (OECD, 2010a), and a large number of inactive young people are not in education or training (Nelms and Tsingas, 2010).

2. The eligibility age for superannuation will be increased to 60 by 2025 . 
Figure 1. Overall labour utilisation
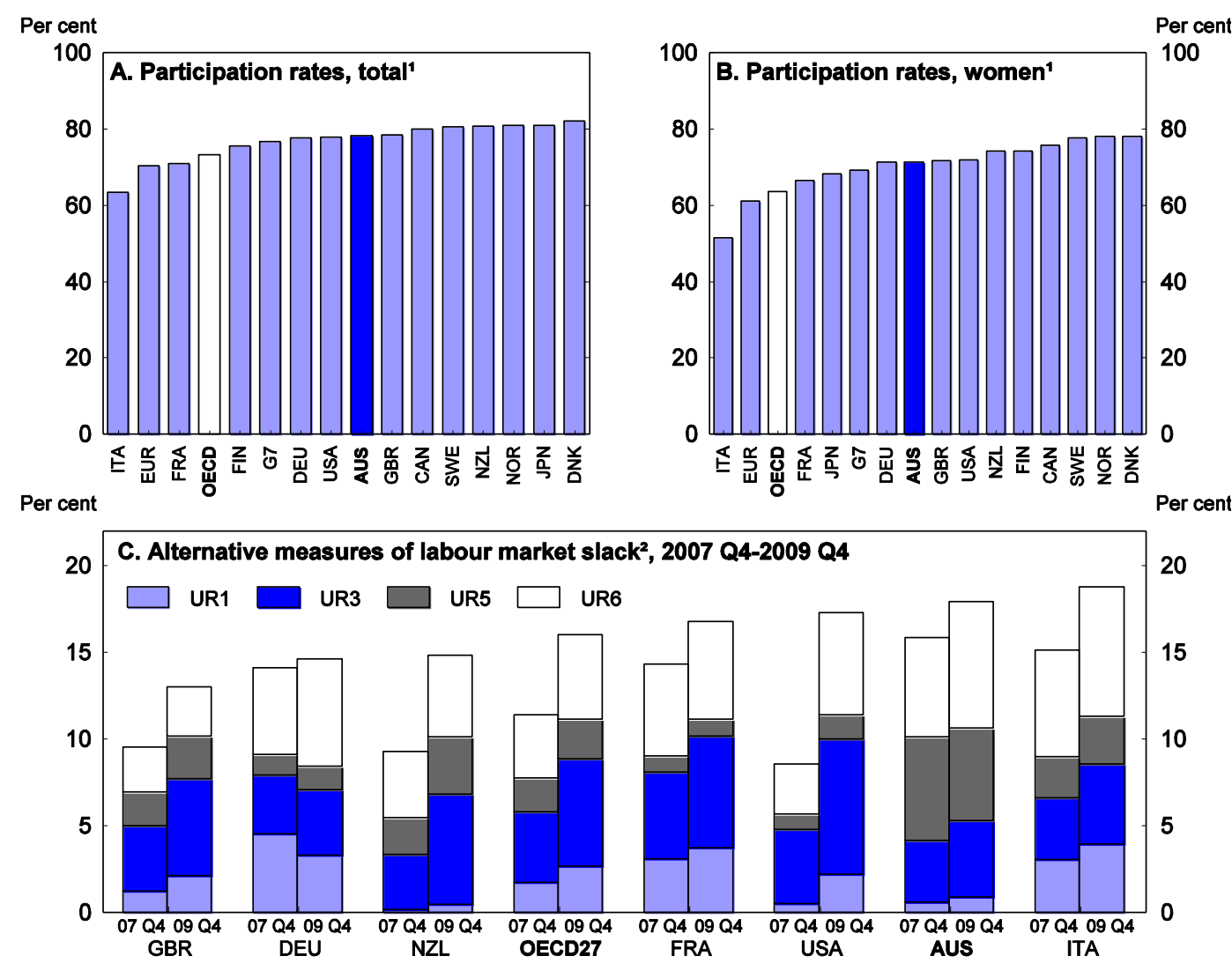

Note: UR1: Long-term unemployed (one year or more) as a percentage of the labour force. UR3: Unemployment rate (ILO definition). UR5: Unemployed plus persons marginally attached to the labour force, as a percentage of the labour force plus persons marginally attached to the labour force. UR6: Unemployed plus persons marginally attached to the labour force plus underemployed workers, as a percentage of the labour force plus persons marginally attached to the labour force. For more details, see OECD (2010), OECD Employment Outlook.

1. Refers to population aged 15 to 64 .

2. Countries shown in ascending order of UR6 in 2009 Q4. Seasonally unadjusted data, except for the United States. OECD27 and G7 are weighted averages. The OECD area excludes the following countries: Korea, Mexico and Switzerland.

Source: OECD (2010), OECD Employment Outlook and OECD, Labour Force Statistics Database. 
Figure 2. Labour market outcomes for specific groups
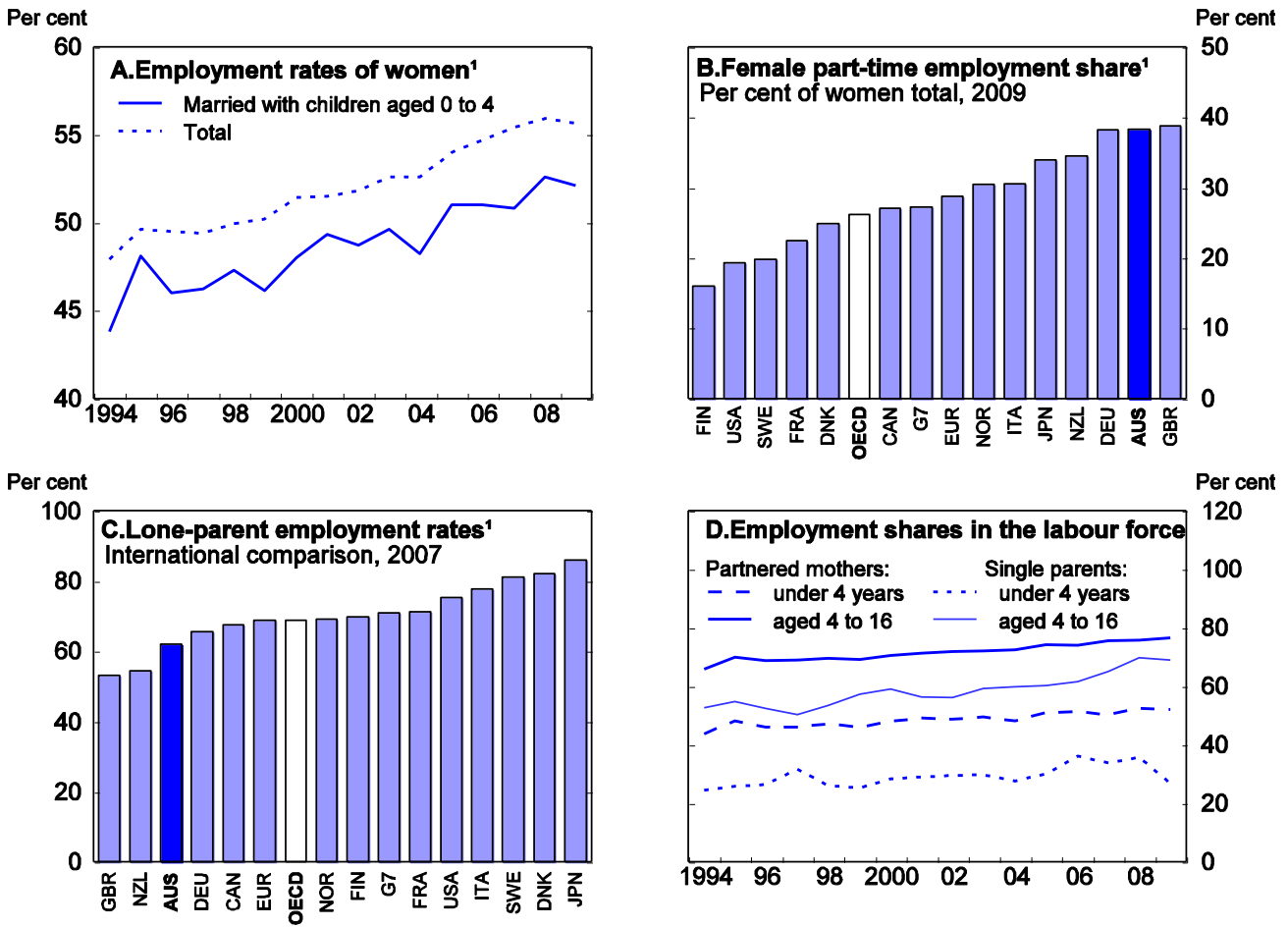

Per cent
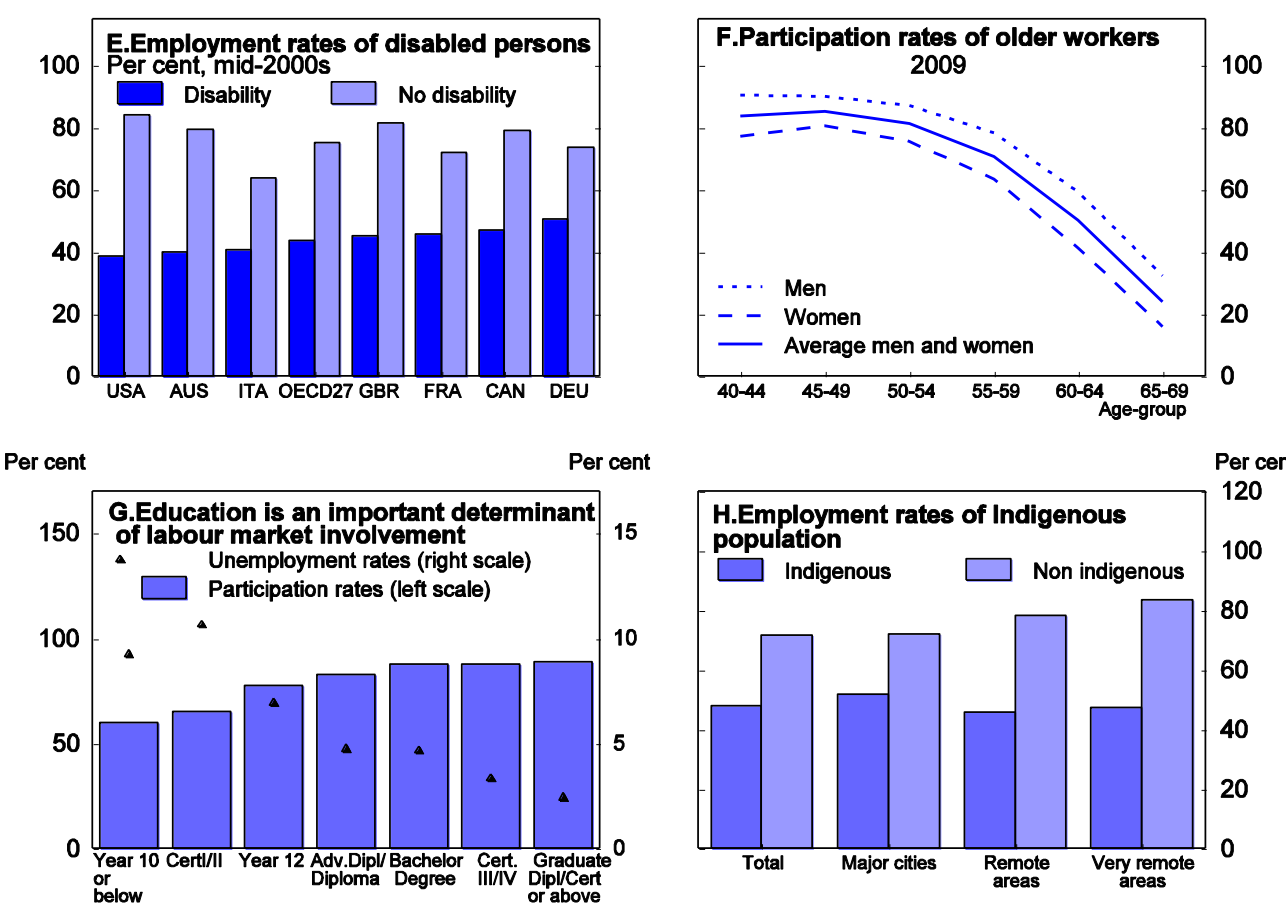

1. For panel $\mathrm{A}$, data refer to population aged 15 and more; for panel $\mathrm{B}$, data refer to population aged 15 to 64 ; for panel $\mathrm{C}$, data refer to population aged 15 to 64 and the latest available data are: 2005 for Canada and 2006 for Australia and New Zealand.

Source: ABS, Labour Force Australia: Labour Force Status and Other Characteristics of Families, June 2010; OECD, Labour Force Statistics Database; OECD Family Database; Centrelink/ABS Labour Force Survey: Annual Family Data, June 1994 to June 2004; OECD (2009), Sickness, Disability and Work, Keeping on Track in the Economic Downturn, Background paper, High-Level Forum, Stockholm; ABS, Education and Training Experience, 2009 and SCRGSP(2009), Overcoming Indigenous Disadvantage, Key Indicators. 
- Indigenous population. The employment rates of Indigenous people (2.5\% of the population) are low compared to non-Indigenous ones, especially in very remote areas (Figure 2, Panel H). This difference persists along gender and age lines. Indigenous Australians are also more likely to be employed on a part-time basis and in low skilled jobs (SCRGSP, 2009). The Council of Australian Government (COAG) agreed to the objective of halving the employment gap between Indigenous and non-Indigenous Australians within a decade, which would require a $63 \%$ rise in the number of Indigenous people employed at mid-2006.

- Recent immigrants. Australia does well in employing immigrants (Figure 3, Panel A), although it takes some years before their unemployment rates reach those of the Australian born (Figure 3, Panel B). Recent immigrants also tend to be vulnerable to cyclical conditions, but those speaking English do better. This partly reflects the less effective transfer of human capital for immigrants from Non-English speaking countries (Australian Government, 2010c). Recent reforms towards a more demand-driven migration policy can have a positive impact on employment outcomes as those in the skilled visa stream have a similar likelihood for full time employment, independent of the country of origin (Figure 3, Panel C).

Figure 3. Migration indicators

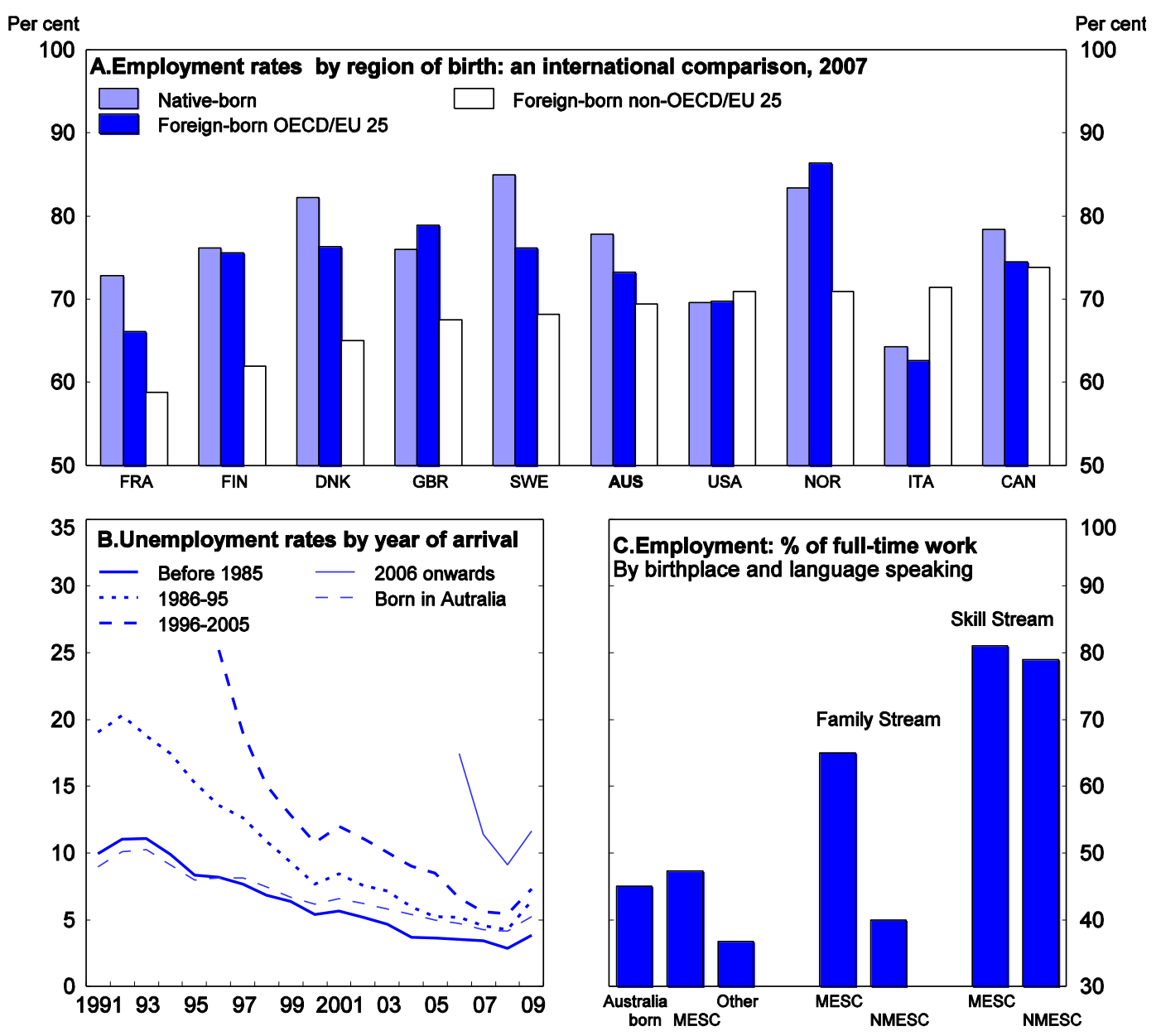

Note: MESC: Main English-speaking countries; NMESC: Non-English-speaking countries.

Source: OECD (2009), OECD International Migration Outlook and Australian Government (2010), Population Flows, Immigration Aspects, 2008-2009 Edition, Department of Immigration and Citizenship. 


\section{Multiple disadvantages lead to social exclusion and weaker labour market outcomes}

Social exclusion is a complex and multi-faceted problem, difficult to measure and address. Apart from lack of access to the labour market, it is influenced by poverty and income inequality, poor educational outcomes, health problems, and social disadvantages such as exclusion from services and lack of social network (Australian government, 2010a). These disadvantages impact on the ability to work, learn and engage in the community (ASIB, 2009). About 5\% of the working age population has multiple disadvantages. ${ }^{3}$ The groups particularly at risk of social exclusion are largely the same as those where labour underutilisation is marked: lone parents, jobless families, Indigenous Australians, people with disabilities, those on low incomes, and new immigrants.

Social exclusion is influenced by income disparities. Income inequality was close to the OECD average in the mid-2000s ${ }^{4}$ (Figure 4, Panel A). However, the gap between the poorest and richest households has widened in recent years. ${ }^{5}$ Australia's poverty rate - measured as households with disposable income below half of the median income - is somewhat above the OECD average (Figure 4, Panel B). Jobless families are overrepresented among poor households. Indigenous Australians, public renters, social security recipients and lone parents are also among the poorest, followed by people with disability (Saunders and Naidoo, 2009). Most of these groups (lone parents, public renters and Indigenous people) are even more disadvantaged when poverty is measured by the "consistent poverty" approach, which covers low income and deprivation. ${ }^{6}$ Indicators of housing stress (discussed below), provide further insights into the risks of poverty.

Poor education outcomes increase exclusion risks. For example, children with a disability, a nonEnglish speaking background, living in remote areas, and from Indigenous groups ${ }^{7}$ are under-represented (compared to the proportion of the relative group in the community) in child care services supported by the government (SCRGSP, 2010) (Figure 4, Panel C). Such care tends to improve overall educational outcomes later in life (Heckman and Masterov, 2007). Students from low socio-economic backgrounds are also around three times less likely than those from high socio-economic backgrounds to go to university (Universities Australia, 2008). Educational achievement varies across social groups. Literacy and numeracy performance is lower for Indigenous students (Figures 4, Panel D). High school completion is much lower among 20-24 year olds living in areas of lower socio-economic status than those from the least disadvantaged areas (ASIB, 2010). People with disabilities and mental health problems may find it difficult to access appropriate education for their learning needs. Only about a third of the working age population with a reported disability had completed upper secondary school in 2003, compared with around 50\% of those without disability (Australian Government, 2010a).

3. Experiencing disadvantage in three or more of six selected economic, social or personal areas (covering income, work, health, education, safety and support) (ASIB, 2010).

4. A number of recent changes in the tax and transfer system may affect summary measures of income inequality: across the board reductions in personal income tax from 1 July 2008, including a rise in the thresholds for low and middle income taxpayers and in the low income tax offset; further cuts in personal income tax from 1 July 2009 and 1 July 2010, focused on lower and middle income taxpayers, as well as further increases in the low income tax offset; and significant increases in pension payments.

5. Updated research by Atkinson and Leigh (2010), provides evidence of increasing concentration of incomes, with the top one per cent having doubled their share of household income wealth since 1980.

6. The deprivation approach provides a sharper differentiation between individuals who can and cannot afford essential items than whether income is above or below the poverty threshold.

7. Indigenous children are under-represented in child care but over-represented in preschool enrolments according to the 2010 Report on Government Services (SCRGSP, 2010). 
Health outcomes remain unequal among vulnerable population groups, although Australia compares favourably with other OECD countries in overall health indicators (OECD, 2009b, Figure 1.1). The gap in life expectancy at birth between Indigenous and non-Indigenous population is around 11.5 years. Disabilities are also more prevalent among the Indigenous population at all ages (Australian Government, 2008). Mental illness is also higher among groups likely to face multiple disadvantages, in particular, lone parents (Figure 4, Panel E).

Homelessness is an important aspect of social exclusion and is comparatively high in Australia, ${ }^{8}$ at about $0.5 \%$ of population since the beginning of the decade. ${ }^{9}$ It is more prevalent in inner-city areas where facilities for the homeless are easier to access, but is not simply a metropolitan problem (Chamberlain and Mackenzie, 2008). The share of homeless families with children increased between 2001 and 2006 (Figure 4, Panel F), and children under 12 now comprise $12 \%$ of the homeless population. This is of particular concern as homeless children are more likely to become homeless when they grow up. Other important homeless groups are older Australians, ${ }^{10}$ people with disability and mental health and Indigenous Australians (9\%).

"Network poverty" is part of social exclusion people need to have someone to turn to at a "time of crisis." This is lacking for several groups those with low incomes, the unemployed, those with poor health, people not proficient in English, and people in jobless homes (ASIB, 2010). Most of these groups also have particular difficulty in "having a say" in their community issues or in influencing decision makers. Finding it difficult to have a say increases as people's self-assessed health deteriorates (Figure 4, Panel G).

Some groups also face difficulties in accessing services, such as banks, health and employment services. This reflects mainly a lack of services in the areas of residence, difficulty with transport, or distance to, and the cost of services (ABS, 2007). People with low incomes, in one-parent families, with disability or poor health, living in remote areas (Figure 4, Panel $\mathrm{H}$ ), public housing renters, the unemployed and jobless families are more likely to face poor access to services than the general population. The gap between Indigenous and non-Indigenous Australians in accessing Internet at home was over 20 percentage points in mid-2000s (ASIB, 2010). The youngest, oldest, Indigenous Australians and people with low levels of education were less likely to seek legal assistance (Coumarelos et al., 2006).

8. See, Fitzpatrick and Stephens (2007). Comparable cross-country information on homelessness is scared. The definition is particularly broad in Australia including people staying with families or friends. This goes some way of explaining the comparatively high rates of homelessness in Australia.

9. $45 \%$ of the homeless population in 2006 were staying with family and friends, $21 \%$ were in boarding houses, 19\% were in a Supported Assistance Programme and 16\% were sleeping out or in improvised dwellings (Chamberlain and Mackenzie, 2008).

10. According to Homelessness Australia (2010), older people are under-represented among people assisted by homeless services: $17 \%$ of homeless in Australia are aged 55 and over but only 6\% stayed in homeless assistance services in 2006-07. 
Figure 4. Indicators of social exclusion
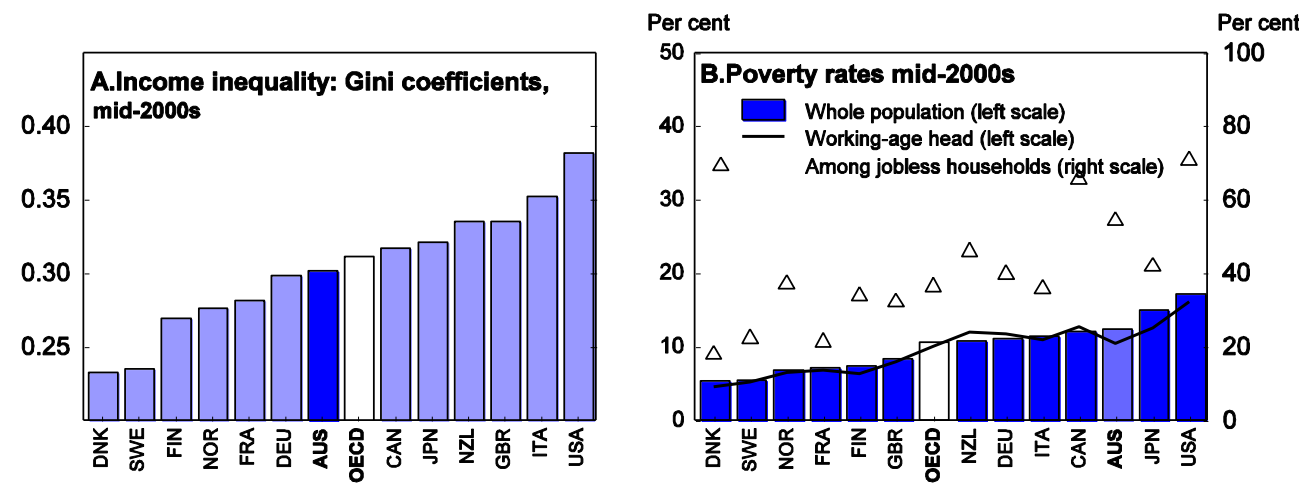

Per cent
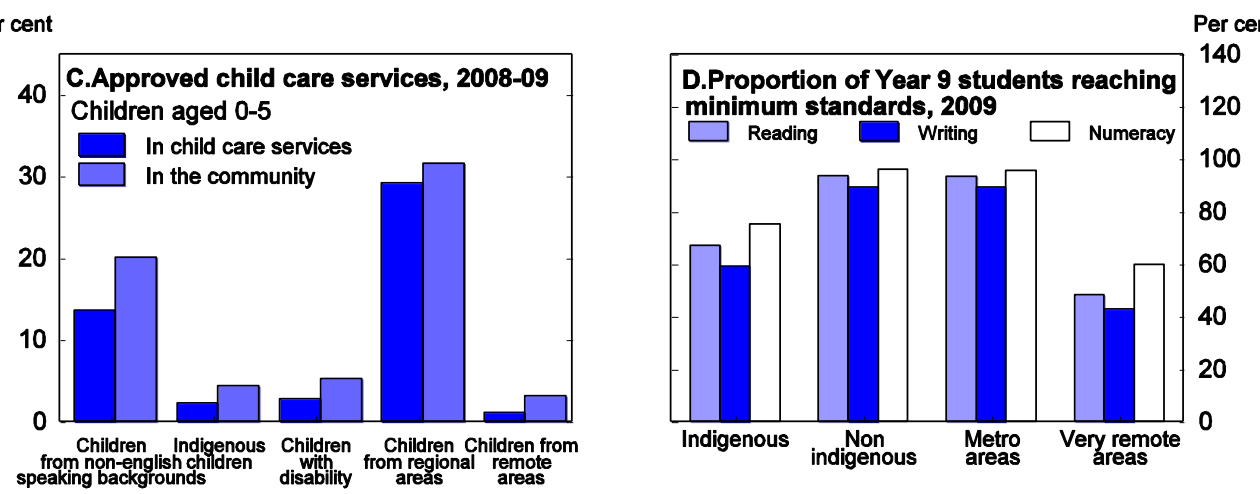
Per cent
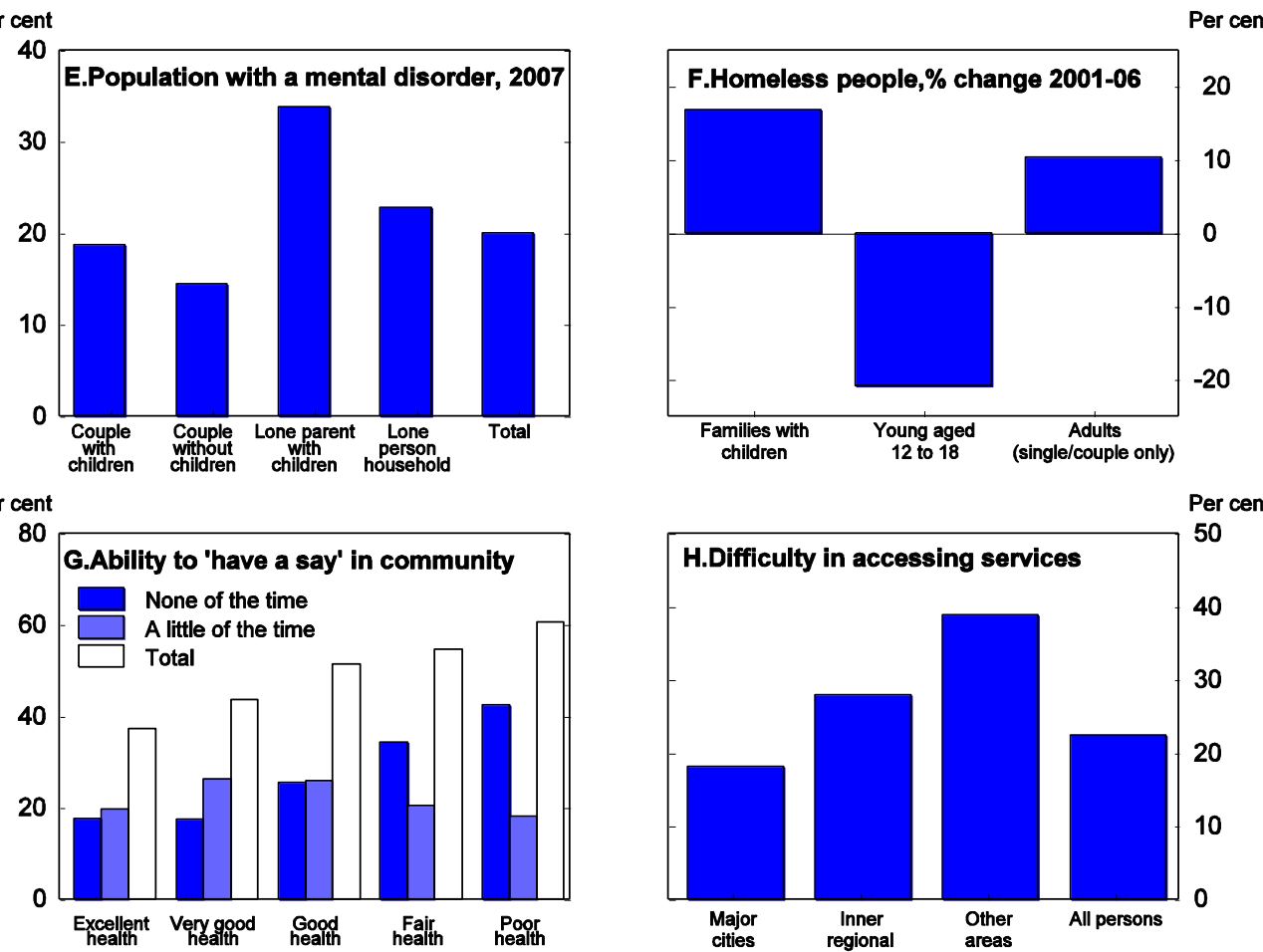

Source: OECD (2008), Growing Unequal? Income Distribution and Poverty in OECD countries; OECD(2009), OECD Employment Outlook; SCRGSP(2010), Report on Government Services; MCEETYA(2009), National Assessment Program, Literacy and Numeracy - Achievement in Reading, Writing, Language Conventions and Numeracy; Chamberlain, C. and D. MacKenzie (2008), Australian Census Analytic Program: Counting the Homeless, 2006, ABS; ASIB (2010) Social Inclusion in Australia: How Australia is Faring? and ABS, General Social Survey. 
Social exclusion in Australia is being tackled at all levels of government and is focused on six most vulnerable priority groups. These are: improving the life chances of children at greatest risk of long-term disadvantage; targeting jobless families with children; reducing the incidence of homelessness; enhancing outcomes for people with disability or mental illness and their carers; closing the gap for Indigenous Australians; and addressing locations of concentrated disadvantage (Australian Government, 2010a). The policies are based on the recognition that simply increasing government expenditure does not necessarily improve social inclusion. Mainstream services also need to be accessible to those who need them most, and initiatives to tackle deficits in areas such as education, health and housing, can be effective in reducing persistent disadvantages. Given the close links between labour market outcomes and social inclusion, the solutions need to cover policies related to the tax-transfer system, labour market, education and training, health care and social housing.

\section{Addressing Australia's future employment needs and social challenges}

\section{The tax-transfer systems need to strike a balance between poverty and incentives to work for disadvantaged groups}

The current tax-transfer system can discourage work incentives of some groups. The flat-rate and means-tested nature of Australia's social security benefits is less costly, more targeted, and more redistributive than in most OECD countries (Whiteford, 2009a). However, the system raises issues of benefit adequacy, horizontal equity and incentives to work (Australian Government 2010d). At the same time, multiple and often overlapping transfers and cumulative withdrawal rates can result in relatively high effective marginal tax rates (EMTRs), especially for second earners (Chapter 2).

Income support benefits are paid at two main rates. ${ }^{11}$ The higher pensions have traditionally been paid to people who were not expected to work (the aged, those with significant disability and their carers and single parents whose youngest child is below 8), and involve more generous participation tests and withdrawal rates. The lower allowances are granted to those having the capacity to work (usually the unemployed and students). The gap between the two is considerable: in 2010 the allowance for a single, unemployed person was $68 \%$ of a pension. Longer term projections show that the allowance would fall to $46 \%$ of the pension by 2040 under unchanged indexation arrangements (Australian Government 2010d) ${ }^{12}$.

The low level of the unemployment allowance (Newstart Allowance) has raised concerns about its adequacy. Unlike most OECD countries, Australia provides a flat (non-earnings related) means-tested allowance to meet social risks such as unemployment, which may be paid for an unlimited period. In terms of other countries' programmes, this can be thought of as combining social assistance and unemployment benefits. The allowance for a single person for the full-year in 2007-08 amounted to 31\% of net median income, which is below the poverty threshold of 50\% of median income (Australian Government 2010d). The resulting net replacement rate is below the OECD average for the initial stage of unemployment. However, it gradually rises above the average, because of its flat and unlimited nature compared to declining and time-limited benefits in many other countries (Table 1).

11. Since September 2009, parenting payment for single parents, although pension, is paid at a lower rate. Also Austudy for full-time students and Australian Apprentices aged 25 years or over is paid at a lower rate than the main Newstart Allowance.

12. In addition to being indexed to price changes, pension rates are also benchmarked to community living standards, as measured in the increases in wages measures (male total average weekly earnings). A third factor, the Pension Beneficiary Living Cost Index (PBLCI), is now taken into account for other pensions apart from the parenting payments for single parents. Allowances, on the other hand, are indexed solely to prices. 
Table 1. Generosity of unemployment benefits

Net replacement rates at different points during an unemployment spell, $2007^{\mathrm{a}}$. In percentage

\begin{tabular}{|c|c|c|c|c|c|c|}
\hline & Year 1 & Year 2 & Year 3 & Year 4 & Year 5 & Five-year average \\
\hline Norway & 72 & 72 & 72 & 72 & 72 & 72 \\
\hline Belgium & 65 & 63 & 63 & 63 & 63 & 63 \\
\hline Denmark & 68 & 68 & 68 & 68 & 9 & 56 \\
\hline Ireland & 50 & 50 & 50 & 50 & 50 & 50 \\
\hline Germany & 64 & 48 & 42 & 36 & 36 & 45 \\
\hline France & 67 & 64 & 31 & 31 & 31 & 45 \\
\hline Finland & 60 & 58 & 33 & 33 & 33 & 43 \\
\hline Australia & 42 & 42 & 42 & 42 & 42 & 42 \\
\hline New Zealand & 38 & 38 & 38 & 38 & 38 & 38 \\
\hline Sweden & 66 & 63 & 41 & 8 & 8 & 37 \\
\hline United Kingdom & 28 & 28 & 28 & 28 & 28 & 28 \\
\hline Canada & 52 & 14 & 14 & 14 & 14 & 22 \\
\hline Japan & 45 & 3 & 3 & 3 & 3 & 11 \\
\hline Italy & 37 & 0 & 0 & 0 & 0 & 7 \\
\hline United States & 28 & 0 & 0 & 0 & 0 & 6 \\
\hline Median & 52 & 40 & 25 & 13 & 9 & 28 \\
\hline
\end{tabular}

1. Countries are shown in descending order of the overall generosity measure (the five-year average). Calculations consider cash incomes (excluding, for instance, employer contributions to health or pension insurance for workers and in-kind transfers for the unemployed) as well as income taxes and mandatory social security contributions paid by employees. To focus on the role of unemployment benefits, they assume that no social assistance or housing-related benefits are available as income top-ups for low-income families. Any entitlements to severance payments are also not accounted for.

Source: OECD (2009), OECD Economic Outlook.

The relatively low net replacement rate in the first year of the unemployment spell raises issues about its effectiveness in providing sufficient support for those experiencing a job loss, or enabling someone to look for a suitable job. There is empirical evidence on skill mismatches in Australia, although it is difficult to single out the impact of the unemployment benefit scheme. Skill mismatches appear to be a problem for a number of groups, including newly arrived immigrants who do not have initially access to social security, immigrants from non-English speaking countries (see below) and graduates from vocational education and training, especially in the case of tradepersons (Karmel, 2007). Mavromaras et al. (2007) conclude that overskilling is persistent in the labour market, with a wide variation in its incidence and wage consequences. The ratio of job vacancies to unemployment has increased between the end-1990s and later in the following decade, but this most likely reflects the strong growth of the economy (OECD, 2008a). However, long-term unemployment in Australia is well below the OECD average (Figure 5). This reflects the close linking of unemployment allowances to active labour market policies, and a well functioning compliance and sanctions regime. ${ }^{13}$ Net impact analyses over the past 15 years, which are a measure of programme effectiveness, have shown that Australia's active labour market programmes are very effective in assisting job seekers into employment.

13. Current arrangements include the retention of a non-payment period of 8 weeks for serious or repeated participation failures, although case management will seek to avoid unreasonable hardship on eligible recipients (OECD, 2006). 
Figure 5. Long term unemployment rate ${ }^{1}$

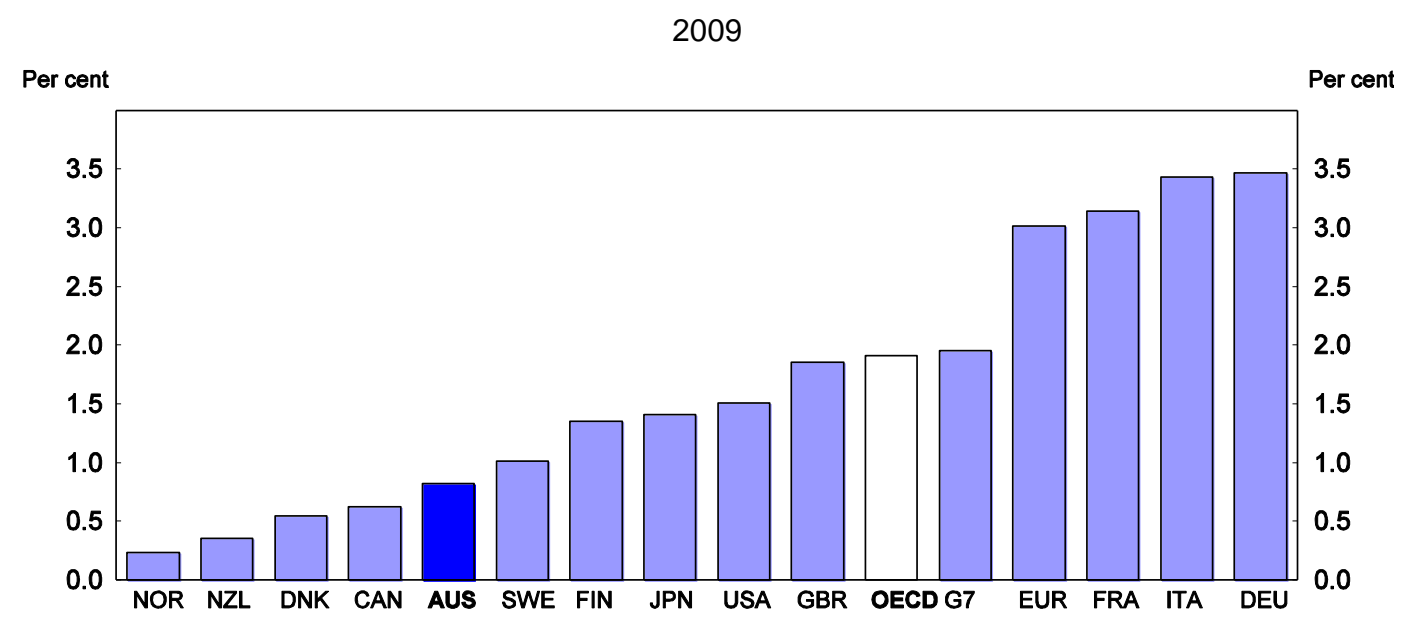

1. One year and over.

Source: OECD, Labour Force Statistics Database.

The large gap between the benefits in the current system can reduce incentives to work. The unemployed may have an incentive to apply for the Disability Support Pension (DSP), which has a higher risk of long-term welfare dependency, although the eligibility for the benefit is determined by a comprehensive, independent assessment of the individual's capacity to work (see below). For example, in September 2009, the net income of a person receiving the Newstart Allowance and working 15 hours at the minimum wage was only about 3 dollars more than the maximum disability pension. Those eligible for pension payments thus have a strong disincentive to work (Australian Government 2010d). Outflow rates from DSP were approximately three quarters of inflows in 2008, but the majority of those leaving DSP does so either because they took up Age Pension or died. At the same time, more than a third of those entering DSP in 2008 had previously had Newstart Allowances.

Financial incentives to work are also weak for single parents at low incomes who are transferred from the parenting payment pension to the Newstart Allowance when their youngest child turns eight. For example, the average effective tax rate for a single parent with a parenting pension working 20 hours per week at the minimum wage (AUD 15000 ) would increase from below $30 \%$ to above $50 \%$ when the child turns 8 years (Figure 6). The significant change in the average effective tax rate reduces the attractiveness of low paid work to single parents, impacting on part time work, in particular (Whiteford, 2009b). On the other hand, the drop in benefit rate facing single parents when their youngest child turns eight may provide a strong income effect to seek work. Parents receiving lower subsidies may also have stronger incentives to apply for a more generous benefit: the second largest group (12\%) that has entered the disability payment system from another income support scheme in 2008 was former recipients of parenting payments. However, for higher earnings (above AUD 15 000) the average effective tax rate under Newstart declines relative to the average rate under parenting pension. Thus, the financial incentive to take a full-time job, even below average earnings, is higher under Newstart Allowances (especially, taking into account the income effect component of the incentive). Moreover, Newstart is subject to activity requirements and a legal obligation to accept suitable work, and the employment service providers generate job offers, which should also have a positive impact on work incentives for single parents. The official evaluation of the 2006 welfare reforms (see below), tightening the eligibility for single parenting payments, provide evidence in this regard (as evidenced by higher exit rates from payments). 
Figure 6. Participation tax rates': Single parent, 2009

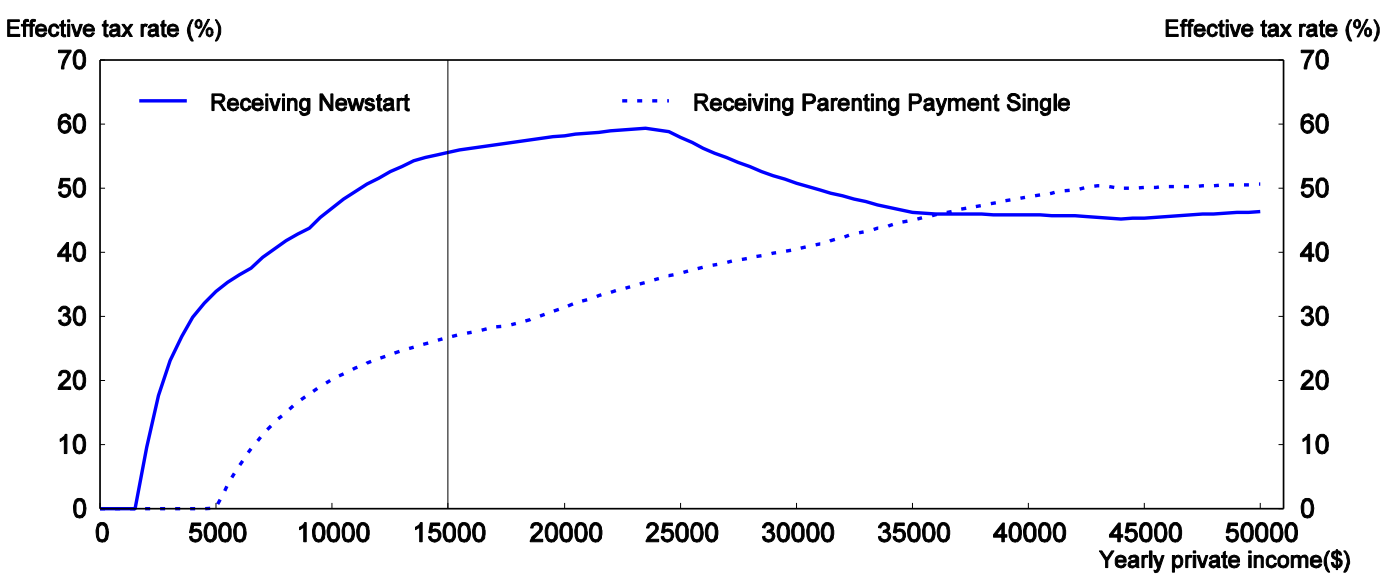

1. The participation tax rate is the average effective tax rate from no work to the level of yearly private income.

Source: Australian Government, The Treasury.

Large differences in the benefit rates also raise concerns about horizontal equity. The present payment structure leads to very different outcomes for people with similar work capacity, because benefit conditions can change markedly for marginal changes in personal or family circumstances. This is for example the case of single parents when their youngest child reaches eight, discussed above.

Work incentives can be reduced by the rise in effective marginal tax rates (EMTRs) as benefits are withdrawn. Many of the tax and transfer policy changes implemented over the past decade were designed to reduce EMTRs and boost work incentives. Despite the reforms, EMTRs can still be high for families with children due to overlapping withdrawal rates of multiple family benefits (Australian Government 2010d). Empirical evidence suggests that a fifth of lone parents and around 14\% of couples with children face EMTRs above $50 \%$. This compares to $3.1 \%$ of couples without children and $2.4 \%$ of single people (Harding et al., 2009). Second earners are particularly affected. This group is taxed more heavily in Australia than in other OECD counties, despite separate personal income taxation for spouses, because means-testing is less common in other countries and the relative generosity of family benefits in the first place. High EMRTs also hit single parents and one-earner couples with children in their transition from part- to full-time work (see Figure 2.11), reinforcing concerns about "low-wage traps" highlighted in previous Surveys. On the other hand, Australia does not stand out in international comparisons with regards to the EMTRs faced by these groups when they move from inactivity to part-time work. However, the large share of jobless households with children the fifth highest in OECD (Whiteford, 2009b) indicates that there is scope for further reducing "inactivity traps". Measures beyond welfare policy would also be important in this regard given the multifaceted disadvantages experienced by such households.

Changes in taxation ${ }^{14}$ introduced since 2008 are expected to have a positive impact on labour supply. Official estimates suggest that around 85000 individuals would be encouraged to enter the labour force as a result of changes in income tax rates and low-income tax offsets. Including additional hours for existing workers, this could imply around 3 million additional hours of work per week.

\section{Employment is affected by access to affordable high quality child care services}

The cost of child care to be borne by parents can reduce the financial benefits from returning to work. Recent research highlights the importance of child care prices on labour supply of mothers (Gong, et al., 2010). Non-price factors, such as availability and quality of services, also affect labour supply decisions of

14. See endnote 3 . 
married women with young children (Breuing and Gong, 2010). The Australian Government provides a subsidy to both working and non-working parents through the Child Care Benefit (CCB) (a means-tested per hour assistance) and a complementary Child Care Rebate (CCR) available to working parents, which cover $50 \%$ of "out-of-pocket" expenses for approved child care, up to a cap. ${ }^{15}$ The CCB rate varies depending on family income, the number of children in care and the type of the care used. The formula for calculating the $\mathrm{CCB}$, and its interaction with the CCR scheme are complex. Although the maximum rates of CCB are indexed to inflation (CPI), this assistance has not kept pace with increases in child care prices in recent years (Australian Government 2010d).

Beyond government funding, supply constraints could also affect affordability of care. As discussed in the previous Survey, there is no clear evidence of a shortage of child-care places, but at the local level anecdotal evidence suggests that parents can experience difficulties in finding care for very young children (0-2 years), or at specific times of the week that match their working hours. Whereas these may reflect complex parental preferences rather than an under-supply of child cares places, the structure of Child Care Benefit (CCB) should take into account the fact that the provision of services for very young children is more expensive.

\section{Reforms in the transfer system and childcare services should boost labour force participation}

Increasing allowances while keeping incentives to work

Measures of relative poverty (described above) indicate that the Newstart Allowance should be raised (subject to fiscal constraints and in line with community expectations that payments are affordable, sustainable and fair) to provide a more adequate level of income support. To reduce the risk for long-term unemployment, however, job-search requirements for benefit eligibility, active labour market policies and a credible compliance and sanctions regime should be maintained. It is important, in this context, to ensure that the new employment services system, with greater emphasis on more disadvantaged, provides adequate incentives for service providers to place job seekers with low barriers to employment (Box 2). In addition, the higher Newstart Allowance could be of a limited duration, with the benefits being gradually phased out over time to their current flat rate. This would not solve problems of adequacy for those remaining on Newstart for a longer period, but it would improve the effectiveness of Newstart as "the first line of defense" for those losing their job, while maintaining incentives to find a job over time. A potential cost of this change, however, is reduced employment incentives, especially for those at low incomes, during the period of the higher time-limited unemployment supplement, an issue that should be carefully studied. Beyond addressing adequacy issues, such a scheme could also improve matching by enabling the unemployed to look for a suitable job. Increasing Newstart for a limited duration at the initial stages of the unemployment spell could also reduce incentives to apply for more generous social security payments, such as DSP, although only on a temporary basis. As noted earlier, more than a third of those entering DSP in 2008 had previously had Newstart Allowances, even though the large majority of exits from unemployment are still towards employment.

15. That is, costs in excess of CCB payments received for approved child care. 
ECO/WKP(2011)21

\section{Box 2. The new employment services system}

The new employment services system, Job Services Australia (JSA), in effect since July 2009, has a number of commendable features. It empowers providers to be more responsive to job seekers and puts greater emphasis on more disadvantaged job seekers through better levels of service. The system is also simpler and more integrated than previous schemes, including only one employment services contract which integrates a range of services previously provided under separate arrangements. The new system entails payments for employment and education outcomes. Higher levels of employment and social inclusion are closely linked to education, as discussed above. In particular, a bonus is to be paid to providers when the job seeker has achieved a successful transition to work and has completed an accredited course in a skill shortage area.

The new system assesses a job seeker for eligibility of services and income support with Centrelink, which is the primary gateway to JSA (private providers and community organisations contracted by the government). The services are demand driven. Every job seeker is linked to a provider of their choice who will have the flexibility to develop individually tailored assistance proportional to the disadvantage of the job seekers. JSA offers four employment assistance streams (Stream Services) adapted to job seekers, depending on the job seekers assessed difficulty of finding employment. This replaces the previous time-based employment services. Job seekers who have completed approximately a year of Stream Services, commence in the work experience phase of their stream or, if they are assessed as requiring a higher level of service, move to a higher stream for another 12 months of assistance; the most disadvantaged job seekers (Stream 4), either move into work experience or receive further assistance in their stream for another 6 months after which they automatically move to work experience.

Care should be taken, however, that the new system minimises risks for "cherry picking" behaviour by getting right the incentives to service providers. There is a widespread view among providers, according to ACOSS (2010), that the JSA funding model offers "scant" resources to assist Stream 1 job seekers, who form half of new job seekers. The structure of payments to providers and the rating system under JSA increases greatly the weight on outcomes achieved for individuals with significant barriers to employment. In particular, in Stream 1, there is a payment to provider for placements but not for "outcomes" (i.e. the placement to jobs that last at least 3 months)* (DEEWR, 2008). Moreover, in terms of the contribution of each stream to overall performance rating, Stream 1 is attached a weight of only $10 \%$ compared to $40 \%$ for Stream 4 , reducing the incentives of providers to place the least disadvantaged job seekers during the first year of unemployment. ${ }^{* *}$ Preliminary evidence suggests poor scores for over half of all providers with a Stream 1 rating (DEEWR, 2010). While it is still early to assess the performance of the JSA system, this issue may have to be revisited in light of experience. Consideration could be given to increase the currently low weight within the performance management system, on achieving employment outcomes for less disadvantaged workers. At the same time it needs to make sure that the new system leads to performance increases for job seekers facing the greatest barriers to work. A frequent monitoring and assessment of the training programmes which are available to job seekers is essential.

* Outcome Payments are not paid for Stream 1 job seekers before they commence in the Work Experience Phase.

** Ratings for each stream measure providers' performance against efficiency and effectiveness that is, the average time required, compared to other providers, to place relevant participants and the proportion for whom placements and outcomes were achieved. They then are averaged, with progressive weights, to calculate the overall rating.

\section{Participation of families with children can be boosted through better work incentives and income support}

A key challenge is to increase incentives to work for sole parents, which is a large socially excluded group. The "welfare to work" reforms, introduced in 2006, shortened the duration of eligibility for Parenting Payment Single pension, with single parents whose youngest child turns 8 moving from parenting payments to unemployment benefits, and introduced part-time participation requirements for parents (both partnered and single) with school-age children. More recently, part-time activity requirements have been refined to include more flexible combinations of job search, work, study or volunteer work. The reforms seem to have improved work incentives, as more single parents with a school age child have left income support. There has also been a small decline in the number of single parents with pre-school age children on benefits (Australian Government, 2010d). Further measures are needed 
however to improve the work incentives for this group. One option is to tighten participation requirements for the parents with pensions coupled with improvements in early childhood education and care services (Whiteford, 2009b). The age of the child at which parents on income support are required to look for parttime work could be reduced gradually from 6 to 4 years, as recommended in the recent tax review (Australia's Future Tax System AFTS), with a simultaneous increase in child services (Australian Government, 2010d).

The incentives to take up low paid work for single parents not eligible for parenting payment (that is, youngest child reached 8 years) could be improved by reducing, finances permitting, the withdrawal rates for Newstart Allowance for low level earnings. This, of course, involves trade-offs in terms of complexity of the benefit system. Care should be taken to strike the right balance between more generous benefits and incentives to work, and sustainability of fiscal policy.

Work incentives for second earners could be improved through a better interaction of the tax and benefit systems. Combining family benefits into a "single family payment", with one withdrawal rate, in line with the AFTS review recommendations, could help to reduce high EMTRs for low-income families arising from cumulative withdrawal rates. Implementation is not easy as there are distributional issues to be considered and complex trade-offs. For example, if the benefit withdraws quickly upon working, there is a risk of an "inactivity trap", where employment, especially, part-time, does not "pay". If the benefit is withdrawn slowly, there is a risk of a "low wage trap". Previous Surveys emphasised the need to reduce low-wage traps, which in Australia are more prevalent than inactivity traps. Suggested measures include, for example, reducing the lowest income tax rate or, increasing the threshold at which income tax is first paid, which Buddelmeyer et al., (2006) judge to have the largest impact on the aggregate labour supply in terms of additional hours of work among alternative options.

\section{Better access to quality child care and family friendly policies would boost employment}

Progress in recent years towards reducing the cost (through increases in the Child Care benefit and Child Care Rebate rates) and increasing the number of child care places is welcome. Going forward, it is essential to ensure the sustainability of the generosity of the Child Care Benefit (CCB), as continuation of recent trends would imply a decline over time in the share of child care costs covered by CCB. In addition, reforms are needed to ensure that CCB is more responsive to differences in child care costs across services and locations to facilitate access by low paid families (Australian Government, 2010d). Combining CCB and CCR into a single (means-tested) payment, set as a percentage of out-of-pocket expenses, would simplify the benefit and address the above concerns. Such a scheme would also take better into account the age-related cost profile of child care provision. To contain pressures on government expenditure and child care fees, in view of the higher responsiveness of an out-of-pocket assistance payment to child care prices, a cap on assistance would be necessary. The child care benefit (currently available to all eligible parents for up to 24 hours per week for each child, without participation requirements) could be made more conditional on employment and job search of parents, except if children face multiple disadvantages.

The planned introduction of a paid parental leave (PPL) scheme in January 2011, in line with international practice, is welcome. Combined with other leave arrangements, the PPL scheme will enable most parents to stay with their infants for at least 6 months. Eligibility is subject to primary carer residency and income criteria and having worked continuously for 10 of the 13 months before the expected birth. PPL will be granted to eligible parents for a continuous period of 18 weeks at the minimum wage rate. The PPL scheme is estimated by the Productivity Commission to increase the average Australian women's lifetime employment by 2 to 6 months. The right granted to parents of a child below school age under the new industrial relations system (see below) to request flexible working arrangements, including changes to hours, patterns (job-sharing) or location, go in the right direction towards improving the family-work balance. 


\section{Activating workers with disability who have the capacity to work}

Inflows to disability benefits could be reduced. Recipients of disability benefits nearly doubled as share of working age population over the past two decades, although the trend has stabilised in more recent years (Figure 7, Panel A). The highest rise was among women and young people (Figure 7, Panel B). Longitudinal data indicate that Australians tend to leave employment more easily than in other OECD countries after the onset of a health problem, with a comparatively high transition rate from employment into disability (OECD, 2009a) and, as discussed above, frequent transitions from unemployment into Disability Support Pension (DSP). These findings suggest that more attention should be paid to monitoring of the sickness absence process of workers, to ensure that as many of those on sickleave return to employment as possible, if able to (OECD 2007a).

Figure 7. Disability indicators ${ }^{1}$
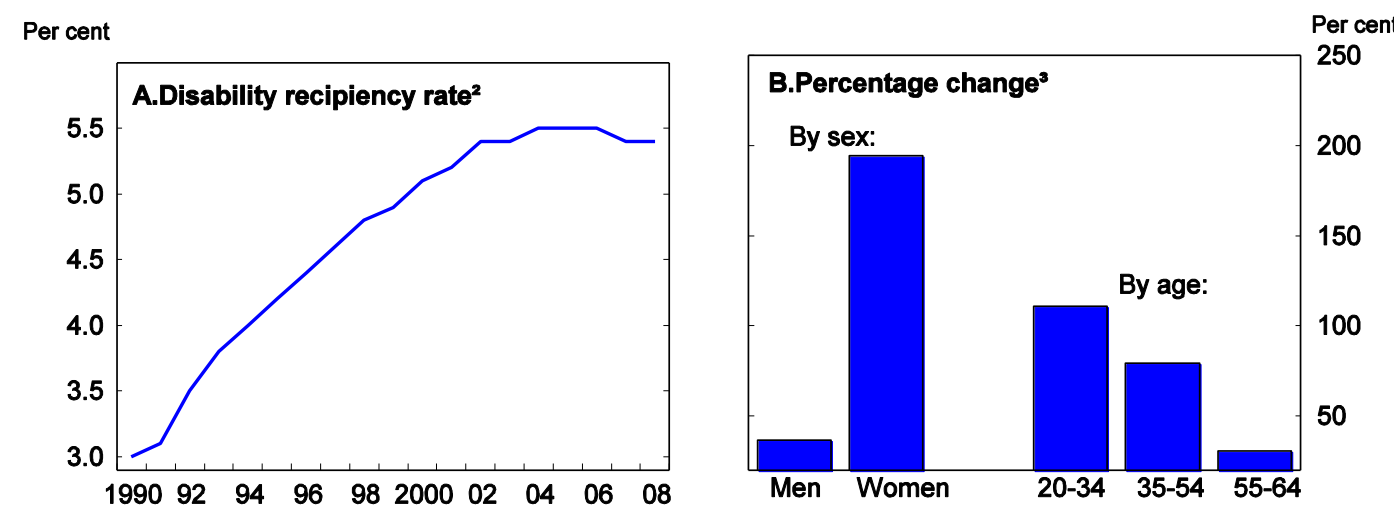

1. Current and suspended customers in June of each year.

2. Number of disability benefit recipients divided by population. Data refer to persons aged 20-64.

3. 1990-2008.

Source: OECD, Directorate for Employment, Labour and Social Affairs.

The effectiveness of the work capacity test for access to DSP could also be tightened. For example, the assessment of capacity to work for less than 15 hours per week, which is required for eligibility, is currently made before most claimants have had any retraining or rehabilitation (Australia Government, 2010d). This means that such an assessment is based on a prediction about a person's future capacity to work, with little information about the likely benefits of rehabilitation. This constrains the effectiveness of any potential change in the eligibility requirements of DSP.

Measures in the May 2010 Budget to reform the process of job capacity assessments go in the right direction, though could be applied to all DSP recipients, including those who were granted DSP eligibility before 2006. The reforms aim at refining the assessment process to place a greater focus on a person's future potential to work, with appropriate capacity building and rehabilitation. From 2012, job capacity assessments will also be based on revised impairment tables, which are being updated to make them consistent with contemporary medical and rehabilitation practice. Most applicants will have to provide evidence that they would be unable to obtain employment, even with appropriate assistance, such as employment service or vocational rehabilitation. Should they not qualify for DSP, they will be referred to an alternative income support payment (such as Newstart Allowance) and offered employment assistance through Job Services Australia (Box 2) or the new Disability Employment Services (DES) system that started in March 2010. The DES programme ensures access to services for all job seekers with disability, attempts to provide the right assistance as early as possible, involves less complex assessments and referral processes, and has a strong focus on outcomes with the greatest rewards when providers find job seekers sustainable jobs. Emphasis is placed on skills acquisitions, especially in areas of skill shortages. 
Recent policy changes have also aimed at removing disincentives for DSP recipients to use employment services to find work. Disability pensioners can currently seek employment assistance without fear of losing their pension through an automatic review of eligibility. This reform, introduced in 2008, appears to have positive results (Australia Government, 2010a). To further improve incentives to work of people with disability able to do so, the generosity of DSP could be reduced although the Australian government has advised in its response to the AFTS review that it would preserve the current income support rates set by the recent Pension Review in line with the community standards.

\section{Labour market institutions should remain flexible}

\section{The flexibility of the labour market should be preserved under the new system of industrial relations}

Australia's labour market institutions work well overall. The tax wedge is low and employment protection legislation is not very restrictive compared to other OECD members (Figure 8). Labour markets also performed well during the global economic crisis. A new system of industrial relations was introduced in July 2009 to strengthen bargaining at enterprise level, widen the minimum employment conditions safety net (i.e., minimum terms of employment and wages) and establishing a right of appeal against unfair dismissal of employees of small and medium-sized firms (OECD, 2008a). The challenge for its implementation is to balance flexibility and legitimate fairness concerns. Flexibility is particularly important in view of the expected structural change from the mining boom and reallocation of workers across sectors (Chapter 1). Ensuring adequate wage differentiation to limit the larger wage increases in the booming sectors and regions from spilling over to the rest of the economy is critical. The enterprise-level bargaining under the new system can reduce this risk by linking wages to productivity gains. It is important that arrangements do not extend beyond the company level, apart from the exceptions already envisaged by the legislation. ${ }^{16}$

16. Under the Fair Work Act 2009, Fair Work Australia can facilitate multiple-employer bargaining for certain kinds of employees, being the low-paid who have not had access to the benefits of, or who face substantial difficulty undertaking, enterprise-level collective bargaining. This includes employees working in areas like child care, aged care, community services, security and cleaning, who are often paid the basic award rate. 
Figure 8. Employment protection legislation and tax wedge
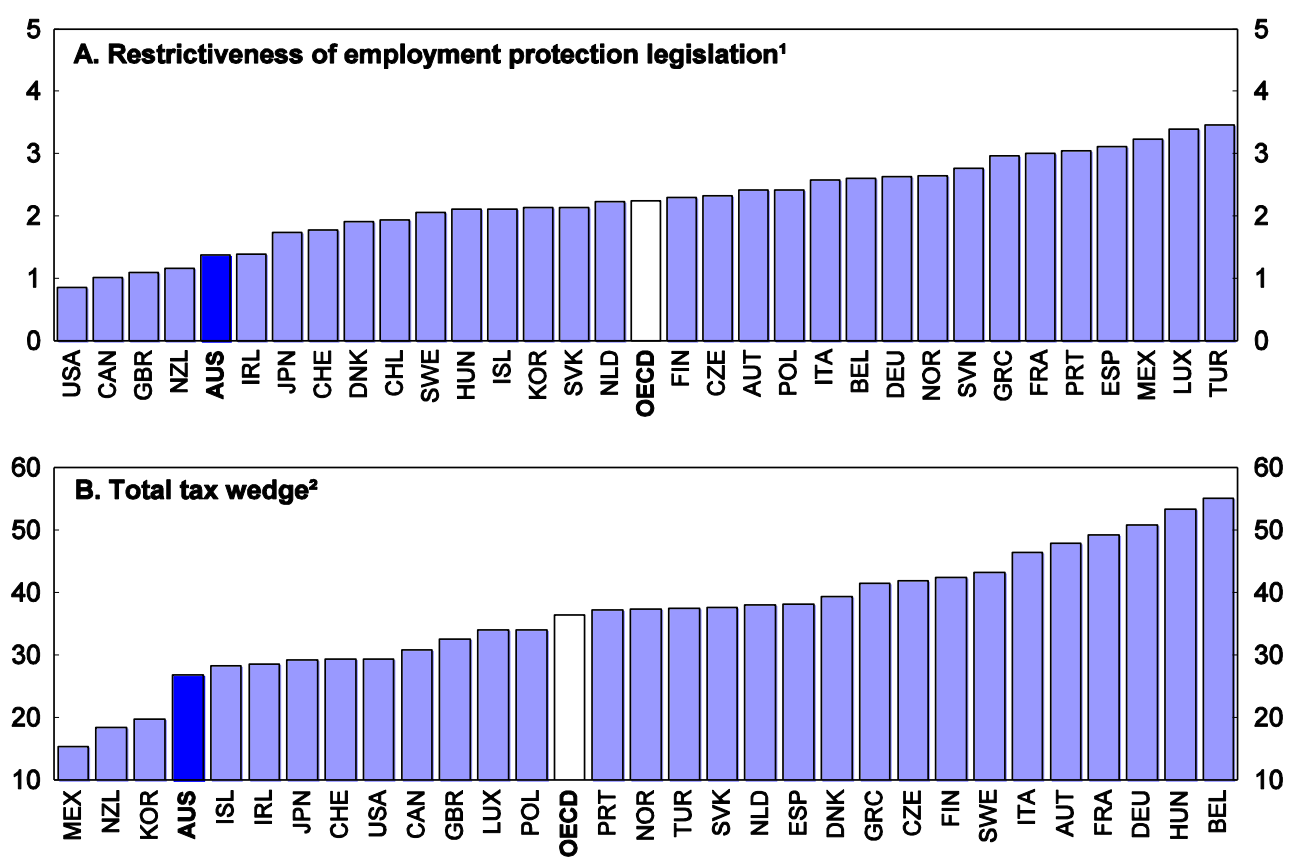

1. The OECD indicators of employment protection are synthetic indicators of the strictness of regulation on dismissals and the use of temporary contracts. Version 3 of the overall indicator is the weighted sum of sub-indicators for regular employment (weight of 5/12), temporary employment (5/12) and collective dismissals (2/12). It incorporates 21 data items and is available for OECD member countries and 10 emerging economies for 2008. For more information and full methodology, see www.oecd.org/employment/protection.

2. Single individual without children at the income level of the average worker.

Source: OECD, Employment Protection Database and OECD (2010), Taxing Wages 2008-2009.

Care needs to be taken that the restoration of unfair dismissal protection at small and medium-size enterprises does not impair labour market flexibility. Empirical studies for OECD countries do not appear to establish a clear link between stricter EPL and employment (OECD, 2007b), nor is there evidence of any link with hiring, firing or working hours of the exemption given to small firms from unfair dismissal under the Work Choices in 2006 (Venn, 2011). The new system of dealing with unfair dismissal claims should, however, be closely monitored to make sure that the administrative costs faced by the firms, especially smaller ones, are not so high as to jeopardize productivity growth and redeployment of labour ${ }^{17}$ (OECD, 2008a). Moreover, the recent government decision requiring companies wishing to qualify for federal government contracts to accept stricter rules for arbitration of industrial disputes than in the Fair Work Act, should be applied so that it does not impair flexibility. ${ }^{18}$ This may imply excluding smaller companies.

17. There was a $39 \%$ increase in the unfair dismissal applications under the Fair Work Australia over the period July 2009 to June 2010 compared to the number received under the previous industrial relations system in 2008-09. This was not unexpected given the enhanced coverage for unfair dismissal.

18. The Fair work Act 2009 does not require enterprise agreements to include third party arbitration, but the Fair Work principle on Procurement does require it as a demonstration of best practice in dispute settlement. Suppliers also have to ensure that their subcontractors comply with principles. Fair work principles are limited to procurements above a specific threshold (Skulley, 2010). 


\section{Minimum wages are not the best tool to fight poverty and social exclusion}

Minimum wages are high in Australia by international comparison (Figure 9, Panel A). In combination with existing benefits, the minimum wage enables full-time workers to escape relative income poverty and promotes social inclusion (Immervoll, 2010). Australia thus has low in-work poverty rates (Figure 9, Panel B). Minimum wage workers tend to be those with low levels of education, older part-time workers, migrants from non-English speaking backgrounds working full-time and those in casual jobs who tend to need a safety net (Nelms and Tsingas, 2010).

Figure 9. Minimum wages and in-work poverty: an international comparison
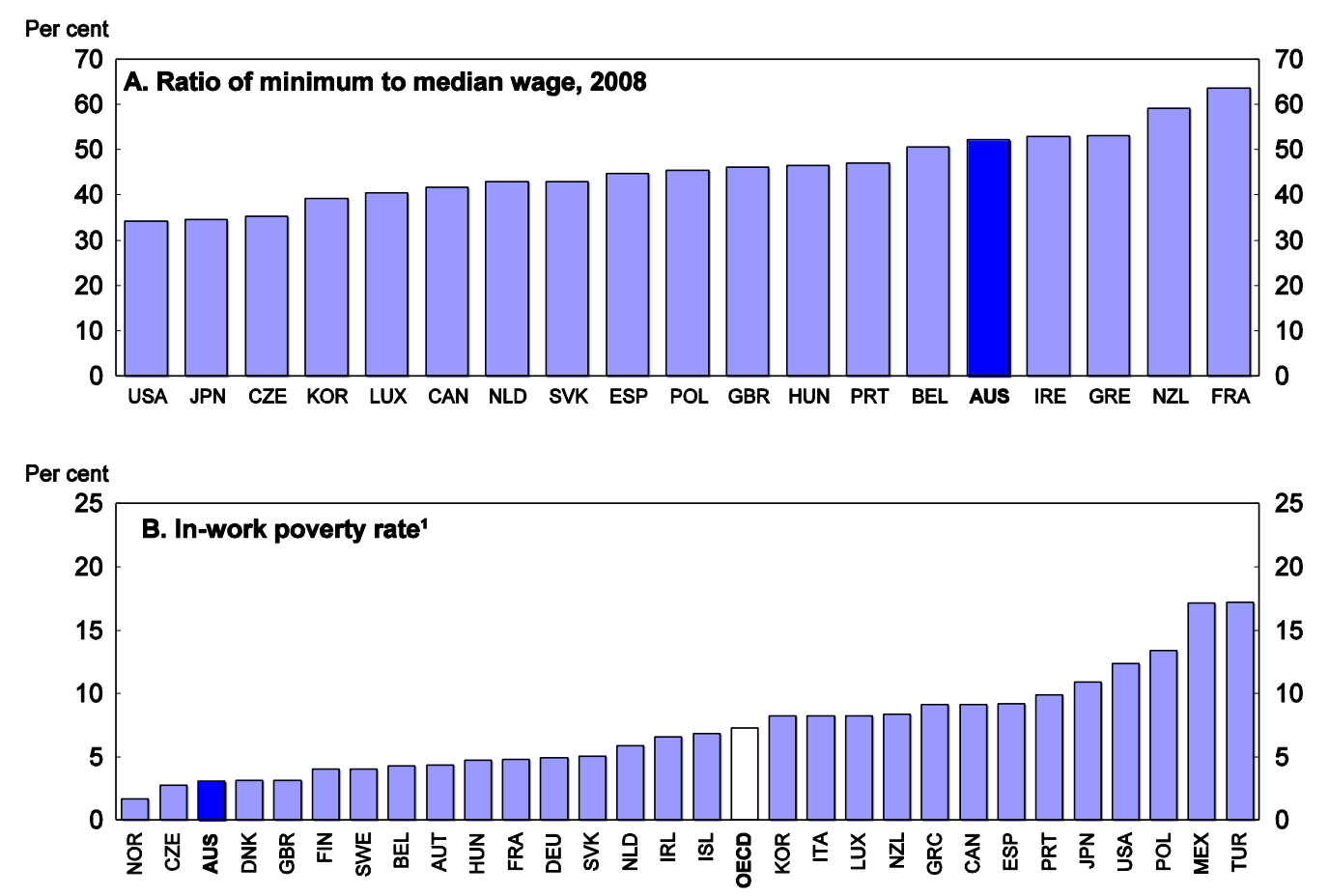

1. Percentage of individuals living in households with disposable income below $50 \%$ of the median income, among all individuals living in a given type of household with a head of working-age and at least one worker.

Source: OECD (2009), OECD Employment Outlook and OECD (2008), Minimum Wage Database.

High minimum wages have mixed effects on labour market outcomes. They may contribute to out-ofwork poverty by reducing employability of low-productivity workers, especially when minimum labour costs are high relative to the cost of an average worker as in Australia (Immervoll and Pearson, 2009 Figure 6). However, there is no clear cut evidence of such a strong disemployment effect, although this may reflect the relative large share of employees (15\% of total, mainly adults) receiving less than the minimum wage (Healy, 2010). Moreover, high minimum wages can increase incentives to work, especially for lone parents (Buddelmeyer and Kalb, 2008). The challenge is to set the minimum wage at a level that minimises the potential employment losses relative to the income gains of lower paid workers (OECD, 2009a). Given the already relatively high minimum wage in Australia, future increases should be moderate and take account of productivity developments to avoid exclusion of vulnerable and low-skilled workers.

In work benefits (IWBs) can be a better tool than minimum wages to address income inequality and support living standards of low paid workers. If employment-related benefits were to be introduced, these could be combined with a lower minimum wage. The previous Survey considered this policy mix to be a potentially better strategy for protecting vulnerable workers by making it easier to get jobs and improving 
their income prospects $(\mathrm{OECD}, 2008 \mathrm{a})$. Australia utilises both the minimum wage and a highly targeted tax-transfer system to reduce income disparities and encourage workforce participation of low skilled workers. More extensive IWBs ${ }^{19}$ could complement the current tax/benefit system, and provide a more comprehensive approach to increasing incentives to work. A growing number of countries have introduced IWB schemes over the past two decades (Box 3) to achieve both employment and distributional objectives. Their advantage over high minimum wage floors is that they can support the incomes of the low-skilled without simultaneously reducing firms' demand for low-skilled workers, or raising EMTRs at low wages (OECD, 2010b). In addition, IWBs can be more targeted than minimum wages at low income earners households. Their disadvantage is that they can lead to higher effective marginal tax rates higher up in the income distribution as they are phased out. Moreover, IWB policies are often criticised as being difficult to administer and/or expensive (Immervoll and Pearson, 2009). Designing an in-work benefit scheme that raises labour force participation, redistributes income and comes at a moderate fiscal cost and without substantially adding to complexity would be challenging in Australia, which already has as a welldeveloped welfare system including generous and extensive family benefits paid to working parents.

\section{Box 3. In-work benefit schemes in OECD countries}

\section{Main features*}

About half of the OECD countries had in place employment-conditional benefit schemes in 2007 with different designs, but too broadly similar dimensions:

- $\quad$ Type of benefit. In-work benefit (IWB) schemes can be transitional or permanent. The former are one-off or time limited payments designed to increase the payoff for moving into a new job, applied in Australia, Belgium, Canada, Ireland, Japan, Korea and Slovak Republic. A larger group of countries (Belgium, Canada, Ireland, Korea, Slovak Republic, Finland, France, German, Hungary, the New Zealand, Sweden, United Kingdom and United Sates) operate permanent IWB programmes which provide payments to a defined group for eligible low-income workers usually in the form of (refundable) tax credits. The generosity of IWBs varies widely across countries, depending on the benefit level and, in the case of earningconditional benefits, the phase-in and withdrawal rates (temporary benefits are usually not income dependent). The number of children also affects the generosity of IWBs in a number of countries. Moreover, IWBs can be conditional on minimum number of hours worked (the United Kingdom, Ireland and New Zealand). The Employment Entry Payment in Australia requires a move into full time employment.

- Beneficiary population. The targeting of IWBs varies across countries. First, IBWs can be targeted towards low paid individuals or low-income families, depending on whether the emphasis is on the employment or distributional objectives of IWBs. Family-based in-work benefits exist in Canada, France, Ireland, New Zealand, Slovak Republic, the United Kingdom and the United States. Second, many countries restrict the entitlement of IWBs to families with children, with the aim of reducing child poverty. Finally, a small number of countries target recipients of social assistance or unemployment-insurance that enter or re-enter employment. Australia, along with Japan, and Korea (until 2009) operate solely this kind of IWBs schemes. The Employment Entry Payment, in particular, is available either to lone parents receiving parenting payment or to long-term income support recipients.

\section{Are the IWB schemes effective?}

Empirical evidence, based largely on the results for the United States and the United Kingdom with the longest experience with IWBs, suggests that these schemes promote employment overall, even though they may reduce incentives to work for second earners (when targeted towards low-income families), or, the incentives for additional work effort (in the case of individual-based IWBs) (Immervoll and Pearson, 2009). In this regard, in-work benefits can reduce poverty. Recent analysis also suggests that permanent IWBs reach low-income families, as in most countries benefit payments start well below the poverty threshold. In addition, the benefit amount reaches its maximum level around the poverty threshold in almost all countries employing such schemes (OECD, 2009a).

What works?

19. Australia has a "transitional" IWB scheme - the Employment Entry Payment - paid as a lump sum to people moving into full-time employment. Benefits are available to a lone parent on income support payment, or long-term support recipient (12 months and above). See, Immervoll and Pearson (2009). 
The cross-country experience shows that IWBs have been most effective in meeting their equity and efficiency objectives when they are large enough to significantly change the benefits of working vis-à-vis not working; are relatively simple to access by eligible individuals and households; distinguish between low-wages and low working hours to ensure efficient targeting; target all low-skilled individuals facing large work disincentives rather than solely families with children; and do not create parallel disincentives to work for second earners (OECD, 2010b).

The effectiveness of the IWBs schemes also depends on a number of "framework" conditions, including the elasticity of labour supply among the targeted groups, the tax system and the shape of the income distribution before the introduction of the scheme. Bassanini et al. (1999) conclude, for example, that a simplified earned-income tax credit system, where workers with higher earnings finance the tax credits for the low paid, yields better overall results in countries with wider income distributions and lower marginal tax rates, such as the United States and the United Kingdom. By contrast, a narrower income distribution makes it much more difficult to target and finance IWBs like in Germany and Sweden, where reservation wages and labour taxes are high. A recent analysis by Immervoll et al. (2007) for EU-15 confirms that a lower tax burden is required to raise revenue for IWBs in countries with relatively widespread distributions. The need for IWBs is reduced particularly in countries with high minimum wages, as they tend to compress the earning distribution at the bottom of the wage ladder (OECD, 2009a). In this context, if employment-related benefits were to be introduced in Australia, these could be combined with a lower minimum wage. To avoid potential disincentives to work for second earners, IWBs could be targeted to groups such as lone parents, given the high degree of labour supply responsiveness of this group to financial incentives (Creedy and Kalb, 2005).

* The discussion draws on Immervoll and Pearson (2009) and OECD (2009a).

\section{Better education and training can reduce educational disadvantages for disadvantaged groups and prevent emerging skill shortages}

Overall, Australia's education system fares well internationally in terms of student achievement, based on the results from the Programme of International Student Assessment (PISA) (Figure 10 Panel A). The education system also fosters intergenerational social mobility, as the influence of parental background on students' secondary education achievement is lower than in many other advanced countries (Figure 11 Panel A). Moreover, Australia ranks relatively high in terms income mobility, with less than $20 \%$ of the earning advantage being passed on from parent to offspring (Figure 11 Panel B).

There is still scope for improvement, however. Despite good performance, gaps in education outcomes remain for some groups (Figure 10 Panel B). The PISA findings suggest that young Australians from low socio-economic backgrounds tend to lag at least one school year behind the Australian average, and more than two years when compared to students in the highest socio-economic quartile. Ensuring equity in education is of great importance not only to help break the cycle of disadvantage but also to increase the employment potential of the economy. At the same time, to sustain growth, the education and training system needs to provide the "right" skills required by a rapidly changing economy and to address skill shortages. Recent projections for the demand for qualifications in the decades to come indicate that about two-thirds of employed people need a higher qualifications profile (Certificate III and higher) by 2015, which rises to 70\% in 2025 (Skills Australia, 2010). Only half of employed people hold such qualifications now. Hence, the future labour force will not only need more skilled people but higher level skills. 
Figure 10. Education outcomes
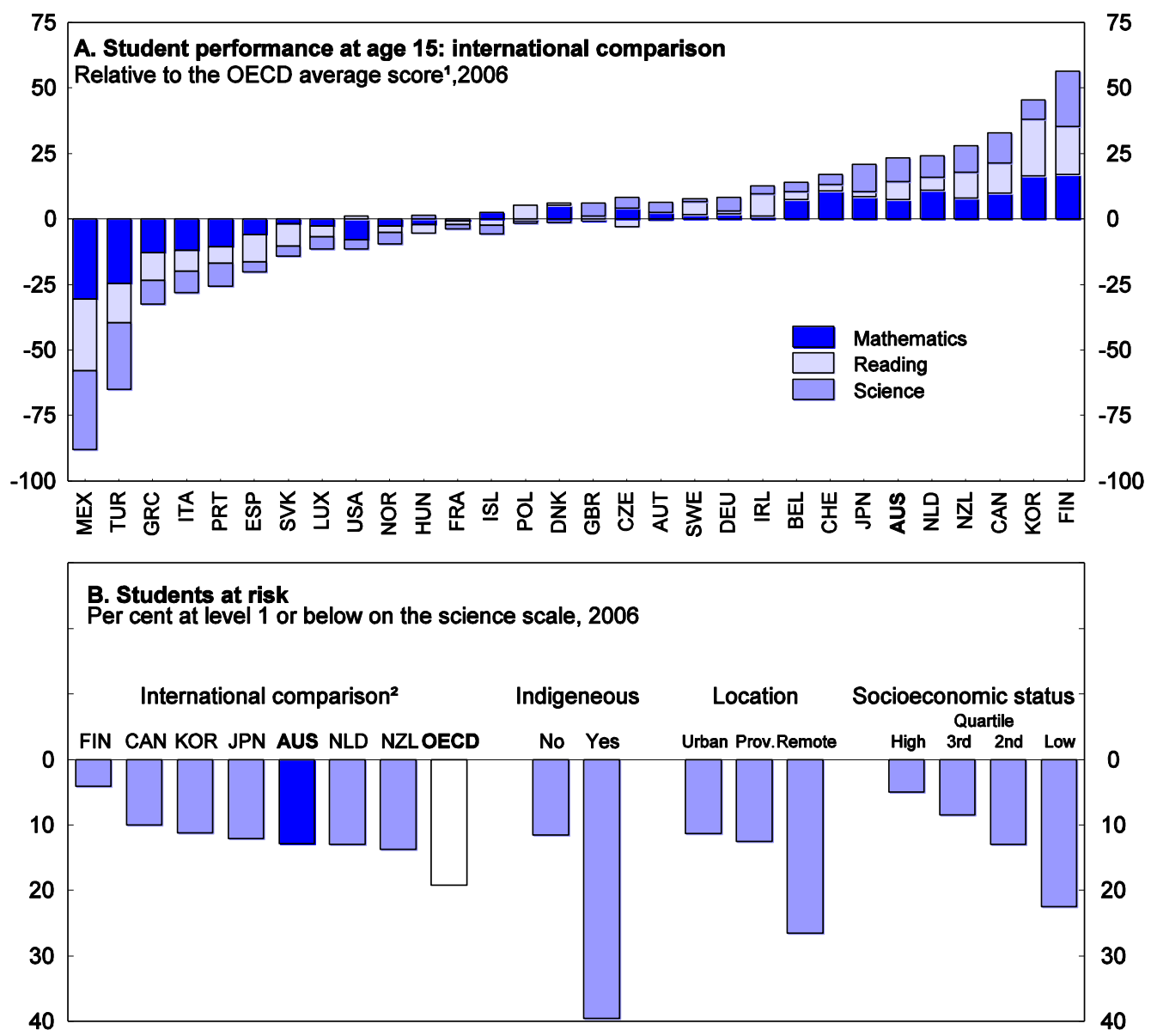

1. The three skills are weighted equally in the total score. Data for the United States in reading proficiency is from PISA 2003.

2. Australia is compared to the six countries with the highest mean performance.

Source: OECD (2007), PISA 2006: Science Competencies for Tomorrow's World and ACER (2007), At Risk Students, PISA 2006 National Report: Fact sheets, Australian Council for Educational Research. 
Figure 11. Education and intergenerational mobility

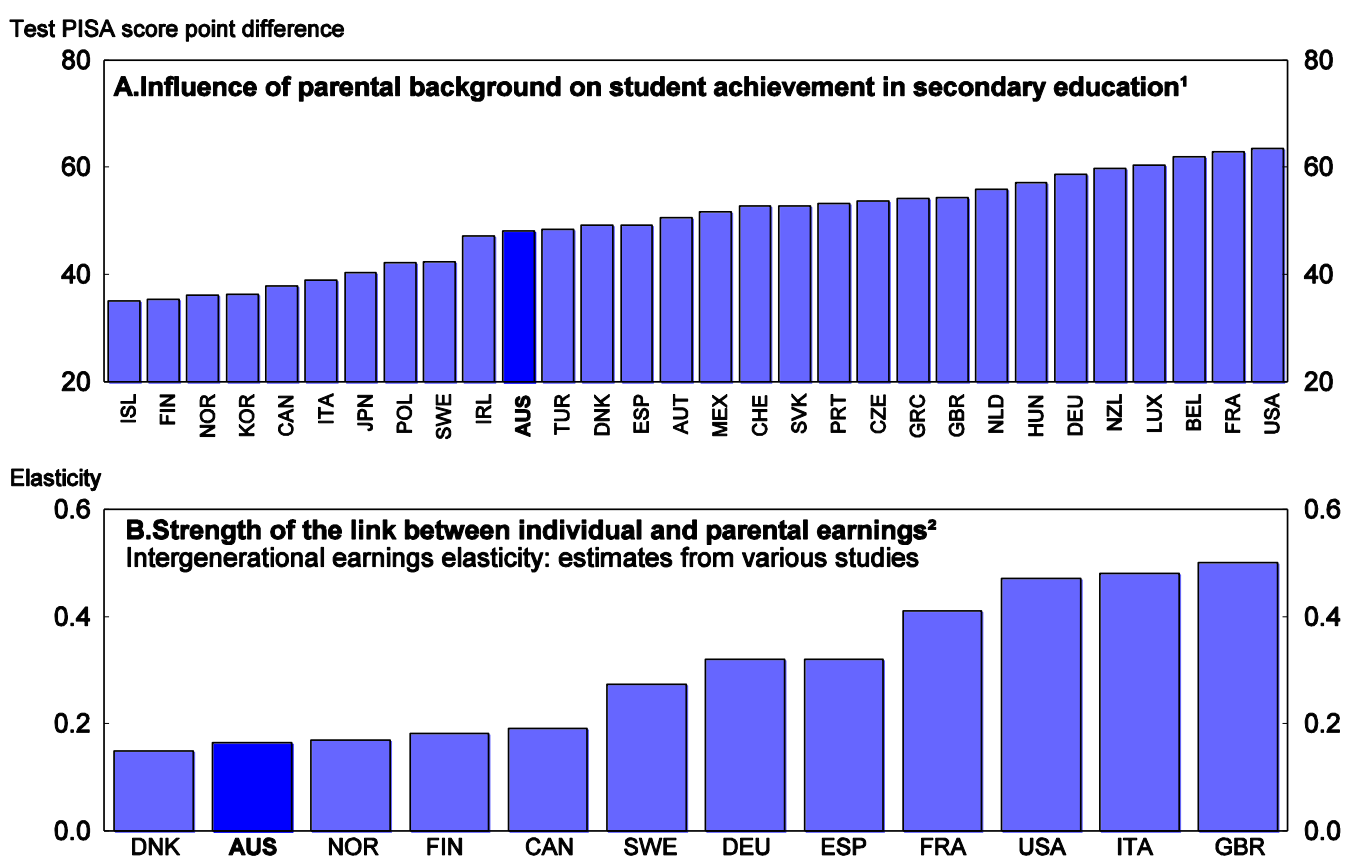

1. Change in PISA science score due to an improvement of one country-specific inter-quartile change in the PISA index of student socio-economic backgrounds. For details, see O. Causa and C. Chapuis, 2009.

2. The height of each bar measures the extent to which sons' earnings levels reflect those of their fathers.

Source: OECD (2010), Economic Policy Reforms 2010: Going for Growth.

A more effective use of immigrants would help to address skill shortages and social exclusion issues for this group. Australia compares well internationally in employing immigrants (Figure 3). This is also helped by the country's immigration policy which favours skilled migration linked to the labour market needs. Recent empirical evidence also suggests good outcomes for children of immigrants in terms of educational (measured by the PISA scores) and employment outcomes (Liebig and Widmaier, 2009). However, there is still scope for improving labour market integration of immigrants, as discussed in the previous Survey. Participation of immigrant women remain low in international comparison (OECD, 2007c). Moreover, while immigrants from the main English-speaking countries tend to perform better than the native-born, those coming from non-English-speaking countries have more difficulties in the labour market and tend to be more exposed to the problem of overqualification (i.e. working in jobs/occupations where the worker is overqualified) (Box 4). 
ECO/WKP(2011)21

\section{Box 4. Making effective use of migration}

Migration is an important contributor to labour supply in Australia, helping alleviate skill shortages (Figure 2.3, OECD 2008a). Net overseas migration currently accounts for around two thirds of population growth. Over the past decade, Australia has increasingly favoured skilled immigration by increasing the size of the Skill Stream within the annual permanent Migration Programme (OECD, 2008a). Migrants are rated with a test that gives bonus points for age, Australian qualifications, fluency in English, and skilled work experience. Another entry option is temporary migration (including international students and business visas). This has grown rapidly in recent years, and now adds more to population than the permanent programme.

Within the skill stream, there has been a marked shift towards demand-driven migration since 2009 with an employer directly sponsoring an overseas worker. Employer sponsored skilled migration places will grow by $26 \%$ in 2010-11, whereas general skilled migration places will fall by $5.2 \%$. A number of reforms are currently underway aiming to better align skilled entry programmes with labour market requirements to help alleviate skill shortages. Initiatives include: a revision of the skilled visa processing priorities to give highest priority to employer and state sponsored visas; a tightening of eligibility requirements for the general stream migration programme through the introduction of a new, more targeted, Skilled Occupations List (reducing the critical skills list from 400 to 181 occupations); and a review of the points test used to assess applicants under the programme to better target skilled migrants. Moreover, reforms to the subclass 457 visa (temporary business long stay visa) increased the protection for temporary workers through the introduction of market-based minimum salary rates for the holders of such visas, although as with all other temporary residents no access is granted to the social support programmes. Official estimates suggest that net overseas migration will fall by $20 \%$ in $2009-10$ (about 56000 people) compared to the previous year in response to changes in migration policies and economic conditions (Australian Government 2010c).

\section{Restrictions on migration would undermine the demand driven approach and potentially exacerbate supply bottlenecks}

Migrants make up around a third of total employment in Australia. However, distinct patterns of labour market outcomes remain, with differences between immigrants originated form English-speaking countries and those from non-English-speaking countries, with the latter group also ranking low in other indicators of social exclusion (see above). In addition, evidence suggests room for a more adequate use of immigrants' human capital, as overqualification tends to be greater for immigrants (OECD, 2007c), even though Australia is close to OECD average. Immigrants from non-English-speaking countries are more exposed to the problem: around half with degreequalifications achieved a professional or managerial outcome, according to the 2006 Census (OECD, 2008a).

Recent moves towards a more demand-driven skilled migration will not only facilitate full-time employment in highly skilled jobs, but reduce social exclusion among immigrants. A more effective system of assessment and recognition of foreign qualifications and experience is still necessary to limit exposure to over-qualification (OECD, 2008a). The development of a national licensing regime, agreed by COAG in April 2009, will contribute to this, as it will introduce a benchmark for offshore assessment arrangements for skilled workers. By removing inconsistencies across states the new regime will also facilitate mobility. It would also be advisable to assess carefully the longer-term impact of restrictive social security rules for newly arrived immigrants (the two-year waiting period before they become eligible for income support) on immigrants' occupational patterns. This policy was found to have a positive impact on the probability of immigrants finding a job, but a negative effect on their probability holding a good job based on previous qualifications (Junankar and Mahuteau, 2005). In case that this initial downgrading has long-lasting adverse effects, the length of the waiting period could be reconsidered, as it was advised by the previous Survey. Making work placements in skills jobs more broadly available during this waiting period which affects eligibility for most job support schemes could help addressing issues of overqualification among immigrants (OCED, 2007c).

Migration will remain an important tool to address skill shortages, especially in light of the critical demographic challenges of an ageing population and the differentiated labour demand across states and industries because of the mining boom (McKissack et al., 2008). Official estimates suggest net migration of between 150000 and 230000 a year would ensure that the labour force continues to grow quite strongly over the next 40 years (Australian Government, 2010b). Migration is also expected to deliver fiscal benefits. The 2008-09 permanent entry programme is estimated by the government to have a positive impact on the budget ranging between AUD 609 million (in 2010) to AUD 1.3 billion (in 2030). To ensure further increases in migration inflows, given their importance for the resource states in the years to come, reforms are necessary to improve water resource management and address infrastructure bottlenecks. Improving housing availability and affordability, and enhancing education and health services are also important issues to be addressed. Migration policy should be pursued as part of a broad strategy of population growth, and in this context, the assessment of migration policy in a long term perspective is welcome. 


\section{Promoting better educational equity can reduce social exclusion}

Early interventions tend to be key to reducing intergenerational inequalities (Causa and Chapuis, 2009). Participation in early education, and spending on such services, are low in Australia (OECD 2008a). Only a third of three to four year olds were enrolled in pre-primary programmes in 2008 - less than half of the OECD average - and public spending on these services at $0.04 \%$ of GDP is a tenth of the OECD average (OECD 2010c). ${ }^{20}$ Many disadvantaged children are left behind, although they have the highest payoff from early childhood education services (Heckman and Masterov, 2007). The Australian Early Development Index also suggests that high proportions of "developmentally vulnerable" children enter full-time school directly from the disadvantage groups (ASIB, 2010). The implementation of the National Partnership Agreement on Early Childhood Education, targeting the provision of universal access to pre-school for all children in the year before formal schooling by 2013, should be a key priority (Box 5). In the longer term and as fiscal circumstances allow, consideration should be given to further improving the quality of early childhood education and extending its access to three-year olds, focusing initially on the disadvantaged groups. Consideration could also be given to extending the duration of provided services, to better accommodate child care and education needs and facilitate labour participation of parents, particularly single ones. Efforts underway towards a less complex and fragmented early childhood education and care (ECEC) system are welcome and need to continue. Greater consistency in policy and services across the child-care and early education sectors would bring benefits in terms of access and service quality, as highlighted by the previous Survey. The relatively low share of employees with a relevant formal qualification and high child-to-staff ratios in approved child-care services raise particular concerns (OECD, 2008a). The National Quality Framework for ECEC, being progressively implemented from 1 June 2010, will improve qualification requirements for child care staff and the staff-to-child ratios.

Increasing the social mix in schools, financial incentives to teachers and effective mechanisms for allocating public resources to schools would promote equality of opportunities and the overall performance of the education system. Teacher quality is critical for skill formation and educational equity (Causa and Johansson, 2009), yet the academic aptitude of new teachers and teacher students has declined over the past two decades (Leigh and Ryan, 2008). The previous Survey recommended changing the system of career progression, which imposes an upper limit for salaries 9 years after graduation, to keep the best teachers. The wage dynamics of teachers' salaries remain weak in Australia in international comparison (OECD 2008a, Figure 3.8). The influence of family background on student achievement is lower in countries where teachers' wage progression is higher. To promote equity in education, the teacher remuneration system should create appropriate incentives for teachers to move to schools where highquality teaching is most needed. Initiatives to ensure that highly performing teachers are recognised and rewarded in schools in low socioeconomic areas are therefore a move in the right direction (Box 5).

20. Statistics on pre-primary education in Australia include preschool institutions but exclude preschool programmes delivered in other early childhood education institutions, such as child care centres. As a result, the reported figures can understate the actual levels of expenditure and participation at the preprimary level. 


\section{Box 5. Recent measures to address education challenges}

Reducing educational disadvantage features high in the policy agenda. Recognising the importance of early childhood development, the Council of Australian Government (COAG) has developed the National Partnership Agreement on Early Childhood Education aiming, among others, to provide by 2013 universal access to quality preschool (delivered by a university educated early childhood teacher) for 15 hours per week, 40 weeks a year to all children in the year before they start school. Reforms are also underway to reduce fragmentation and complexity in the ECEC sector, through replacing current licensing and quality assurance processes by a unified national system, and providing a single set of national quality standards, incorporating an Early Years Learning Framework. Children will benefit from improved staff qualifications and staff-to-child ratios, while annual benchmarking will monitor preschool participation of disadvantaged Indigenous children.

In the school sector, the Smarter Schools National Partnerships target additional resources to the most disadvantaged schools and help to ensure that highly performing teachers are recognised and rewarded in schools in low socioeconomic areas. Particular attention is given on early intervention in primary education to improve literacy and numeracy skills of underperforming students, especially for Indigenous students (Australian Government 2010a). Publicly available information on individual school performance (My School website) and contextual information about the school also aim at improving outcomes for disadvantaged children. Finally, in various locations in Northern Territory and Queensland, the income support payments to parents became conditional on child school attendance. The COAG's agreed target for school education is to lift the Year 12 or equivalent attainment rate from around $75 \%$ to $90 \%$ by 2015 , and to halve the gap in literacy and numeracy in the Year 12 attainment rate for Indigenous people by 2020.

At the tertiary level, following a comprehensive review of the sector (the Bradley Review), significant reforms are being implemented to raise participation among students from low socio-economic backgrounds by easing the highly restrictive conditions for accessing the student income support scheme and an uncapping of university places. The age of dependence for the purposes of receiving student support will be lowered ${ }^{*}$ and the personal income test and family income test thresholds will increase, allowing students who work to keep more of their income support. Other initiatives include the Higher Education Participation and Partnerships Program (HEPPP) and the new Performance Funding framework for universities. The HEPPP targets directly students from low SES backgrounds through outreach activities, as well as financial incentives and funding for necessary intensive support for universities. In addition, the proposed Performance Funding framework for universities includes financial incentives for universities to enrol students from low SES backgrounds. The move to an uncapped system from 2012 onwards is expected to enable around 50000 new students by 2013, helping to meet the set target that $40 \%$ of all 25-34 year olds will attain a bachelor level qualification or above by 2025 (Australian Government 2009a). A more robust quality assurance process, through an independent national quality and regulatory agency, and performance funding, with reward funding attached to targets for teaching quality, participation and completion rates will provide additional benefits.

Moreover, a strategy for skills was announced in the May 2010 Budget (the Skills for Sustainable Growth package of AUD 660 million over four years), complementing measures taken during the downturn (Australian Government, 2009b). This aims at: i) addressing emerging skill shortages through the provision of new training places, co-funded with industry, in resources and related sectors, and further support for apprenticeships including a more flexible competency-based apprenticeship system and extension of ongoing programmes (Kickstart); ii) delivering literacy and numeracy courses for up to 140000 Australians to develop their foundation skills; and iii) increasing the quality and capacity of VET system, as well as its transparency and comparability. Announced initiatives in this regard include expanding income contingent loans for higher VET qualifications in return for significant training reforms by the states, the establishment of a National VET regulator, and provision of information (My Skills website) on the performance of vocational institutes in assisting unemployed people to choose training options better matching their needs (Australian Government, 2010e).

* Students' eligibility for income support (Youth Allowance) is assessed against parental income and assets. The age of independence from parental means testing is 25 . Students at, or above, this age are eligible for meanstested Austudy grants while younger students who can demonstrate financial independence, through meeting specific workforce participation requirements, are eligible for Youth Allowance. The age of independence is set to be reduced from 25 years to 22 in 2012 .

Additional funding to the low socioeconomic status (SES) schools is also welcome and may have greater payoffs than is anticipated in light of recent evidence that good quality schools are an effective crime prevention strategy (Leigh, 2010). Counteracting the effects of weak SES backgrounds on 
performance would further benefit from better taking into account the difference of socioeconomic backgrounds between students in school funding. ${ }^{21}$ Delivering on a 2007 election commitment, the government has commissioned a comprehensive review into the funding arrangements for schools to report by end 2011. The review will provide recommendations for a funding system that is transparent, fair, financially sustainable, and effective in promoting educational outcomes for all students. Accountability, autonomy and choice are important determinants to student achievement (Wößmann et al., 2007). The recently introduced nationally consistent testing system of literacy and numeracy standards of school students (NAPLAN), along with the provision of information (My School website) on individual school performance, are welcome steps towards strengthening accountability and monitoring outcomes for less disadvantaged students. The single national school curriculum, currently under development, would also contribute to this end. Giving autonomy to school principals in recruiting and rewarding teaching staff would help to attract and keep experienced teachers (OECD, 2008a). The new government has committed to introduce a range of school reform initiatives aiming to increase the responsiveness and quality of teaching and schooling. These include reward payments for best performing teachers and schools delivering improvements across areas (such as school attendance and literacy and numeracy performance), as well as enhancements to principal autonomy.

Australia's Higher Education Loan Program (HELP) - an income-contingent government loan provided to tertiary students to cover the cost of tuition - is an innovative programme, setting a model for other countries (OECD, 2008b). However, educational disadvantage at the tertiary level could be reduced further through better income support mechanisms for financially weaker students, as recommended in the previous Survey. HECS helps students to overcome fee-barriers to higher education, but students also need support in the years of study. A relatively large proportion of undergraduate students (23\% of full-timers and $37 \%$ of part-timer students) reported that they regularly missed classes for work related reasons, especially in the case of Indigenous students (James, et al., 2007). A reform of the student income support system is currently underway following a comprehensive review of the system (Box 5). The government's target is to have $20 \%$ of higher education enrollments at the undergraduate level from low socioeconomic background by 2020 .

\section{Increasing the capacity of the vocational education and training system would reduce skill shortages}

The vocational education and training (VET) system is a well developed, flexible national qualification system that actively engages employers and allows people of all ages to participate (Hoeckel et al., 2008). To further improve the system, however, it should be made more responsive to changing skill needs. The high exit rates of apprentices during training (around 50\%) is a very important policy issue in view of skill shortages (Karmel and Mlotkowski, 2009). A number of reasons, both employment- and training-related, such as alternative job opportunities, low training wages, and the long duration of contract term can be risk factors for completion rates. There also has been a sharp fall in the 15-24 year old apprenticeship commencements during the economic slowdown (declining by $23 \%$ in trade occupations in the year to March 2009), that may reflect the fact that apprentices tend to be concentrated in industries where employment itself is cyclical or the high costs to employers of supervising apprentices during a downturn (Karmel and Misko, 2009).

Initiatives in recent years have aimed to increase the flexibility of the training system. Regarding apprentices, reforms in 2006 and recent commitments by the Council of Australian Governments, are moving to competency-based apprenticeships from time-based approaches. However, these reforms need to be translated into action, as in practice apprenticeships still tend to have standard lengths. New measures were introduced during the downturn to sustain apprenticeships, helping commencements to return to their

21. Under present arrangements the federal government is the primary source of public funding to nongovernment (private) schools, while government (public) schools are mainly resourced by the states. For a discussion on the drawbacks of the current federal funding model, see OECD (2008a). 
pre-recession levels (Gillard, 2010). These include incentive payments for employers upon completion of apprenticeships and, subsidies for hiring redundant apprentices. ${ }^{22}$ The 2010-11 Budget announced further action on apprentices (Box 5). An Expert Panel was appointed to analyse apprenticeship training arrangements, and Fair Work Australia is also examining the consequences on setting minimum wages from a shift from time-based apprenticeships to competency-based ones. A key focus of the measures in the latest budget is on tackling literacy and numeracy deficits and improving the quality of the VET system. The initiatives include the establishment of a national VET regulator and the provision of Commonwealth support to the states for training improvements (including access to training). The provision of financial support, which includes access to income contingent loans for eligible VET students, is also key to stimulating demand for these programmes and improving the capacity of the training system to meet skills needs.

Steps towards reforming the vocational education and training (VET) system are welcome and need to continue. A more flexible apprenticeship system hinges upon the effective implementation of competencybased apprenticeships. An overhaul of the training packages (providing a comprehensive list of the competencies required to work in an industry sector and ways to assess them) is also critical, making them less cumbersome and more frequently updated to meet changing skill demands. Designing training packages around generic tasks, rather than certain jobs, could increase their attractiveness for students who want to study in a certain area but do not have a particular job in mind (Hoeckel, et al., 2008). A national assessment procedure to determine whether the necessary skills have been acquired would be necessary and in line with international experience. Greater competition in VET would increase its labour market responsiveness. The 2008 Learning for Jobs: OECD Review of Vocational Education and Training recommended enabling students entitled to public funding to choose providers, highlighting at the same time the need for ensuring that competitive pressures do not limit the quality and quantity of provision to students from disadvantaged backgrounds (Hoeckel, et al., 2008). VET represents the main pathway for Indigenous students to continuing education and schooling, as they are, in general, less likely than their non-Indigenous counterparts to obtain a high enough score for university entry (SCRGSP, 2009). The majority of the Indigenous students, however, are at lower-level VET courses which may not meet the demands of employers. In seeking to address the issue, one should assess carefully the shorter term employment concerns against the potential benefits for VET courses to promote intergenerational mobility of Indigenous Australians by offering them a stepping stone for social and economic market integration.

\section{Social inclusion calls for comprehensive service delivery}

\section{Much can be done to improve social inclusion of people with disability and mental illness}

People with disability need comprehensive support services to deal with a combination of homelessness, poor health, limitations in the capacity of education system to meet special needs, and lack of social networks. Shortcomings in the current system of disability services and support is a critical issue. The system is considered, according to a recent survey among people with disability, as being highly fragmented, under-funded and under-resourced, with large unmet demand and wasted resources on managing demand and rationing services. Effectiveness is also reduced by a "one-size-fits-all" approach (NPWDACC, 2009).

A range of services is funded by the government, but people with disabilities and their families have no guaranteed access to specialist disability services. In 2007-08, it is estimated that a fifth of the population ( $0-64$ years) with profound or severe disability accessed disability support services delivered by the states (broadly, in-home accommodation support, community access, community support and respite

22. These include a Securing Australian Apprenticeships initiative to help employers keep apprentices and the Apprentice Kickstart, which began in December 2009, tripling first year incentives for employers to take on young apprentices in trades like building and construction, electro-technology and engineering. 
services). Disability employment services provided by the Commonwealth were accessed by $16 \%$ of people with profound disability (COAG Reform Council, 2010a). It is difficult to assess the level of current unmet demand for services as there are no available data. Proxied by the proportion of people with profound disabilities who need assistance, $43 \%$ stated in 2003 that they needed more assistance than they are currently receiving, especially among the 15-24 age group (COAG Council Reform, 2010a). While this figure needs to be treated with care, as it includes the need for informal assistance, it is indicative of underlying pressures in the existing system. This is likely to increase further, as the population with a high level disability is projected to grow over the next 70 years (between two and three times the overall population growth rate), and the availability of informal care is set to decline (DIG, 2009). A more effective disability service system is needed, especially for those with mental health problems. Around a third of disability support pension inflows in 2008 were due to mental and psychological problems, especially for younger groups.

Efforts underway to improve disability policies (Box 6) are welcome and should continue, with a special focus on people with mental illness. Addressing better the shortcomings in the current system of support and services is critical, as the government has recognised. A less fragmented and complex system would facilitate access to services and improve quality. The revised national standards for health care, currently under development, are an appropriate policy initiative in this regard, including state specific legislation, sector accreditation and professional regulation. Efforts towards developing a national quality assurance system for disability services are welcome.

\section{Box 6. Policy initiatives to promote employment and social outcomes for people with disabilities}

The government is taking steps to develop a National Disability Strategy (NDS) to guide disability policy across states and territories. The strategy aims to improve the opportunities of people with disability to participate in social and economic life through the better performance of the disability service system and mainstream systems for people with disability and their carers in a whole-of-government, whole-of-life manner (NPWDACC, 2009).

Recent government initiatives further include an increase in income support to people with disabilities and their carers through the Secure and Sustainable Pension Reform package. The government also increased funding for state disability services through the National Disability Specific Purpose Payment under the National Disability Agreement (NDA) providing approximately AUD 5.8 billion over a five year period to states and territories starting in 2008-09 (around $0.5 \%$ of GDP in 2009-10 dollars). Under the NDA, which commenced in January 2009, state governments have committed to a number of reforms, including a person-centred approach to service delivery, simplified access to services, improved measurement of unmet demand, quality assurance and benchmarking. There is also a renewed focus on early intervention and planning to ensure that people with disabilities receive a timely and appropriate support. Increasing access to services for Indigenous Australians is also a priority action area under the agreement (Australian Government, 2010a). Support and services will be further enhanced by the National Mental Health and Disability Strategy, encompassing a new demand-driven Disability Employment Service (discussed above) and incentives to encourage employers to hire people with disability and/or mental illness.

Mental health is a priority area in the disability reform agenda. The Fourth National Mental Health Plan, an agenda for a collaborative government action over the period 2009-14, provides a framework for developing a mental health system for early intervention based on integrated services in health care and social domains, with particular attention on support for children and young people. This is because mental health problems can appear in childhood and infancy. The initiative has so far had positive results in terms of health outcomes and high degree of satisfaction with the services (Australian Government 2010a; 2010f).

In addition, the Fourth Plan has a focus on social inclusion. This is to be achieved by the development of integrated approaches between health, education, employment, housing and aged care systems sectors and health support services (Australian Government, 2010a).The May 2010 Budget set out, under the comprehensive health reform package (Chapter 2), some additional initiatives for mental health care (AUD 176 million over four years), including an extension of early intervention services for young people 12-25 years, individualised care packages for people with severe mental illness in primary care, and an expansion of community-based residential mental health services, providing an alternative to hospitalisation. 
Problems associated with mental illness tend to be less severe and of shorter duration when detected and treated early (COAG, 2006). Early intervention is, therefore, a better and less costly approach than hospital care. The extension in 2010 of school-based early prevention programmes to pre-school and longday care services and recent budget initiatives to this end need to continue. Also, moving swiftly to a more individualised approach to services as agreed by the governments under the National Disability Agreement and lifelong planning for individuals with disabilities, are indispensible to help them prepare for key transitions, such as young people moving from school to work or leaving home (DIG, 2009). This can be achieved by making the system of services more client-oriented. Individual planning must help people with disabilities to develop new skills and realise their potential. Better integrated mainstream systems such as health, housing, education for people with disability and/or mental illness, increased coordination between mainstream and specialist disability services, and an effective system of employment services are important for improving participation outcomes for people with disabilities. Furthermore, the welfare system needs to be reformed in a way that does not reduce work incentives (see above).

Access to community-based residential health services also needs to improve. According to some analysts, $40 \%$ of the acute beds in public hospitals could be freed up if there were better community-based services for people with mental illness (Breusch, 2010). This would reduce costs of hospitalisation, and facilitate social inclusion. Some steps in this direction were taken in the latest budget, but efforts need to continue (Chapter 2). COAG agreed to do further work on the scope of additional mental health reform in 2011. Encouraging people with mental illness to seek assistance is also of great importance only a quarter of young Australians aged 16-24 years who had a mental disorder in 2007 used mental health services in the previous year (ABS, 2010b).

Long-term solutions to funding and delivering disability services are also needed to meet the growing pressures on the system. A feasibility study, commissioned by the government from the Productivity Commission, is currently underway. Better measurement of demand for disability services is essential to design a system that will meet future needs and develop population benchmarking of key service types one of the priority areas under the National Disability Agreement. Further data development is also necessary to develop sound performance indicators of the disability services system (COAG Reform Council, 2010a).

\section{Addressing homelessness}

Reducing homelessness is of key importance to combat social exclusion. The causes of homelessness are many and diverse, and often interacting, including problems of housing affordability, long-term unemployment, mental health problems, addiction and family violence. Housing is deemed to be "affordable" when a low income household (in the bottom $40 \%$ of disposable income distribution) pays no more than $30 \%$ of its gross household income on housing cost (ASIB, 2009). Homelessness can be a oncein-a-lifetime event, a cyclical phenomenon or a chronic condition. For many people, especially young ones, the experience of homelessness can lead to an entrenched disadvantage, and exclude them from full social and economic participation. This in turn can exacerbate existing problems, such as mental illness (AIHW, 2009).

Addressing homelessness is an integral component of the government's social inclusion agenda. The White Paper on Homelessness (The Road Home 2008) sets out a new national response to the problem, with new investment and reform of existing services. The White Paper adopts two headline objectives: to halve overall homelessness by 2020 and to provide shelter to those who seek it by that date, setting interim targets for 2013 to measure progress towards these objectives, (FaHCSIA, 2008). The focus of the strategy is on prevention and early intervention through tackling the structural drivers of homelessness, such as shortage of affordable housing and targeting groups at risk, including Indigenous Australians and women faced with family violence. Emphasis is also put on breaking the cycle of homelessness by rapidly connecting homeless people to long-term housing, while assisting them to reconnect with education, employment and the community so that homelessness does not recur. 
The social inclusion agenda on homelessness is administered through the National Affordable Housing Agreement (NAHA) (AUD 6.2 billion over five first years). In addition to funding public social housing, NAHA has provided funding to states for housing and specialist homelessness services since 2009. The federal and state governments have agreed to work together to reduce homelessness, improve housing affordability and reduce Indigenous disadvantage (AIHW, 2009).

Other reform initiatives underway include an expansion of social housing (both new dwellings and renovating) under the Nation Building Economic Stimulus Plan and partnership agreements on homelessness, social housing and remote Indigenous housing planning. The National Rental Affordability Scheme is offering financial incentives to encourage the supply of new housing to be rented out to low income households at below market rents. ${ }^{23}$ Innovative housing models to break the cycle of homelessness are also under development. The Foyer model provides young homeless people, or those at risk of homelessness, affordable accommodation along with support and guidance to job search and get improved skills and education. Further benefits are expected from the introduction of specialist community engagement officers (CEO) in Centrelink (the agency delivering a range of government services) to provide outreach services to homeless people, or those at risk of homelessness, who have difficulty in accessing mainstream services (Australian Government, 2010a). These officers will also collaborate with local service providers to help prevent homelessness. It is expected that the CEOs will have 216000 contacts per year.

These policy initiatives are welcome as a comprehensive and co-ordinated approach is needed to support the affected groups across their full range of needs, given the multi-dimensional nature of the problem. Improving housing affordability for low-income households is a central element in this regard. Nationally, more than $37 \%$ of low-income renter households were in rental stress in 2007-08, and $47.5 \%$ of those households were in the private rental market (COAG Reform Council, 2010b). Declines in the supply of low-rent private rental dwellings and in the social housing stock as a proportion of total stock have exacerbated pressures (NHSC, 2010). Hence part of the approach to reducing homelessness and housing stress should be to increase the supply of appropriate low-rent housing. Recent government measures under the National Rental Affordability Scheme, which offers financial incentives to the business sector and community organisations to build and rent dwellings to lower income households, are expected to boost the private rental stock housing affordable to low-income household, although they have not yet had a substantial impact (NHSC, 2010). Social housing, accounts for only 4-6\% of the housing stock in Australia, paying a smaller part in housing supply than in European countries (Cowans and Maclennan, 2008). This is targeted at households who may have both low incomes and other disadvantages. However, it is set to increase through the funding provided by the Nation Building Economic Stimulus Plan. In some remote rural regions, social housing may be the only accessible housing for Indigenous people. It is important to ensure that any additional supply of low-rent housing is closely tailored to the household status of tenants, and provide them with access to housing in locations that facilitate social inclusion. Provision of accommodation options is of great importance for people with disabilities, especially those with mental health problems.

However, social housing is a relatively expensive way of providing assistance, compared to rent subsidies in the private rental market and it tends to reduce incentives to work and geographical mobility as people get locked into subsidised dwellings. It also tends to be poorly targeted, raising equity concerns with regards to those renting privately, with similar means, who receive less subsidy (Australian Government, 2010d). Under current arrangements, low-income households receiving income support or family payments and renting privately can receive payments towards their rental costs through

23. The scheme is offering financial incentives (Commonwealth refundable tax offset or payment and state direct or in kind support) to the business sector and community organisations to build and rent dwellings to low and moderate income households at $20 \%$ below-market rates for 10 years. 
Commonwealth Rent Assistance scheme ("rent assistance"), the structure of which has been carefully designed to minimise its costs while targeting those who need it most. Alternatively, low-income households may be eligible for public housing, where rents are typically set at a maximum of $25 \%$ of tenants' incomes, the implicit assistance being the difference between the rent charged and the market rent. As of 2009, more than one million households were receiving rent assistance, at a cost of AUD 2.6 billion, while about a third of a million households were in public housing, receiving a subsidy of AUD 1.6 billion (Australian Government, 2010d). Public housing is thus relatively more costly to fund (per household) than rent assistance because the subsidy element is relatively more generous. To remain on a waiting list, potential tenants must be on low income, which can discourage job search and degrade their human capital. Employment rates of public housing tenants are far lower than those in private rented accommodation (30\% compared to $80 \%$ for males).

To promote equity, work incentives and efficient provision of social housing, consideration could be given to allowing public housing tenants (except those in the remotest rural areas) to access rent assistance, while charging them rents that are close to, or even at, the market rent, as proposed by the AFTS review. Care should be taken that the new system ensures equity in access to social housing while it attempts to address efficiency concerns.

The effectiveness of the rent assistance system can also be improved. Its low cost per household reflects in part a lower degree of assistance than envisaged when the system was put in place. The rent caps for maximum assistance are indexed to the consumer price index (CPI), but the rent element of the CPI has risen considerably more than the overall CPI in recent years. Consequently, those living on low incomes, and especially on other social transfers, are obliged to use a rising part of their incomes to pay their rents. More generous rent assistance, indexed to the rent component of the CPI, or to market-rate rents actually applied to dwellings occupied by those benefiting from income support as suggested by the AFTS review could be considered, provided that upward pressures on rents are contained (Chapter 1) and fiscal costs are not prohibitive. In any case, the principle of co-payment of rent by tenants must remain.

Affordable housing is of major importance in reducing homelessness. Some people, however, may have access to affordable housing but are not able to keep it. Severe mental health illness, for example, may mean that people forget to pay the rent. In the case of homeless youths, care settings that replicate as far as possible a family situation may be more important than housing affordability (Johns, 2010). This highlights the complexity of the needs of homeless people and the importance to ensure that the way services are delivered can provide the full range of support, on an individualised basis, for these people. Involvement of homeless people in service planning and evaluation is important in order to adequately respond to their needs (for example, specific needs for housing of aboriginal population). The development of a national research agenda on homelessness, to improve the evidence base for tackling the problem is a welcome step. Performance benchmarks for inclusion in the National Affordable Housing Agreement, as recommended by the COAG Reform Council (2010b), would allow a better monitoring of progress towards achieving outcomes.

\section{Improving the governance of policy actions is important for effective results}

Better coordination among the various groups responsible for the delivery of services would make implementation of the Social Inclusion Agenda effective. While the respective responsibilities of states' and the Commonwealth has been clarified by the National Action Plans, implementation seems to lag behind announced objectives in important areas, including for Indigenous Australians. The first reports by the COAG Reform Council assessing performance against National Agreements in health care, housing, Indigenous reform and disability confirm the "overwhelming disadvantage" of the Indigenous population in all these areas (COAG Reform Council, 2010c). A key problem is efficient service delivery to people with multiple disadvantages. For example, young children may not attend school if their health problems go undetected, or housing provision may need to be accompanied by instructions on how to pay bills on 
time. Such experience highlight the need for a comprehensive approach, that also engages the disadvantaged groups at an early stage of the policy process to adequately respond to their demand, as for example, the case of housing of the aboriginal population mentioned earlier.

All these factors reinforce the need for a close collaboration among - and within - various levels of government, and non-government providers. While this is already being recognised by the government, further gains could be achieved through an individualised approach in line with that adopted by the new employment services system. As discussed above, the system links each job seeker to a provider who has the flexibility to tailor services to the specific conditions of the job seeker. Support for people facing multiple and entrenched disadvantages should cover their full range of needs and be provided by a multidisciplinary team which would plan carefully on an individual basis.

Going forward, the further development of the comprehensive set of indicators for social inclusion developed by the government will be critical for measuring progress in addressing disadvantage among individual groups or highly vulnerable neighbourhoods or regions. ${ }^{24}$ The gaps in data were highlighted by the COAG Reform Council. Accountability could be further enhanced through the frequent reporting of the social inclusion outcomes against pre-set targets. The commitment of the government towards setting up a framework to regularly measure and report on social inclusion outcomes is a welcome and indispensible step for the development and implementation of effective policies (Box 7).

\section{Box 7. Increasing labour supply while addressing social inclusion}

Future policy improvements in the area of social policies will also need to ensure the long-term sustainability of the government's finances.

Labour market participation and social inclusion can be improved by reforms to the tax-transfer and child care systems

- To improve the safety net for the unemployed, consider raising, the Newstart Allowance for a limitedduration, the fiscal situation permitting. Maintain job-search requirements for benefit eligibility, active labour market policies and a credible compliance and sanction regime.

- $\quad$ The new system of employment services needs to provide balanced incentives for service providers to place unemployed clients from all streams. The training programmes need to be frequently monitored and assessed to ensure that they can help job seekers facing the greatest barriers to work.

- $\quad$ To improve work incentives, tighten participation requirements for the benefits received by parents with young children, while improving early childhood education and care services.

- Reduce marginal effective tax rates. Consider further cutting rates at low income or raising the tax free threshold. Consider moving to a "single family benefit" and simplifying cumulative withdrawal rates. The withdrawal rate of such a "single" benefit should avoid low wage traps.

- Make the child care benefit more conditional on employment or job search of parents, except when children face multiple disadvantages. The benefit should reflect better the differences of costs across locations and the higher cost of services for very young children. This can be achieved by moving towards a simple and adequate structure of child care subsidies, set as a percentage of out-of-pocket expenses. The cap on assistance should be maintained.

- $\quad$ Proceed with the announced introduction of paid parental leave scheme in 2011.

- $\quad$ Continue efforts to improve the job capacity assessment for people with disability. The new assessment process should be applied to all recipients of Disability Support Pension (DSP), including those who were granted DSP eligibility before 2006 .

24. Vinson, 2007 concludes that the most disadvantage $3 \%$ of localities across the country have at least twice the average share of unemployment, long-term unemployment, disability support, criminal convictions and imprisonment. People in remote and rural areas also have less access to high quality services (see above). 


\section{Maintain labour market flexibility}

- Ensure that the new industrial relations system results in adequate wage differentiation by not extending collective bargaining beyond the company level.

- $\quad$ Given the already relatively high minimum wage, future increases should be moderate and take account of productivity developments to avoid exclusion of vulnerable and low-skilled workers.

- A carefully designed in-work benefits system could be explored as part of changes to existing income support and tax arrangements to reduce disincentives to work.

Labour skills and social inclusion would benefit from reforms to the education system and a more effective use of immigration

- Continue steps towards enhancing access to the early education and care (ECEC) services for more disadvantaged groups, while ensuring quality of services. Move swiftly to an integrated ECEC system.

- $\quad$ Proceed with plans to provide universal access to preschool for all children in the year before formal schooling by 2013. In the longer term and as fiscal circumstances allow, consideration should be given to continuing to improve the quality of early childhood education, and extending its access to three-year olds, focusing. Initially on disadvantaged groups. Consideration could also be given to extending the duration of services.

- $\quad$ The system of teacher career progression in the public sector should change so as not to cap salaries nine years after graduation.

- Modify the school funding mechanism to take adequately into account differences in the socio-economic backgrounds of students. Pay more to attract good teachers to schools servicing disadvantaged students.

- $\quad$ Proceed with the ongoing reform of the student support system for higher education students aiming at improving targeting and raise the level of assistance of those most in need.

- Proceed with the implementation of the announced strategy for skills. Move swiftly to competency-based apprenticeships. The training packages should become less cumbersome and be updated regularly to meet changing skill demands. Introduce a national procedure to assess whether the necessary skills have been acquired.

- Maintain demand-driven migration policies. Make work placements in skilled jobs more broadly available and enhance the effectiveness of the system of assessment and recognition of foreign qualifications in order to a make a better use of immigrants' human capital. Proceed with the development of a national licensing regime, as agreed by COAG, and the introduction of a benchmark for offshore assessment arrangements for skilled workers.

\section{Improving outcomes for people with disability and mental illness would enhance social inclusion}

- $\quad$ Pursue efforts to improve disability services, especially for people with mental health problems. Reduce the fragmentation and complexity of the system. Proceed swiftly with the development of the revised national standards for health care. Develop a national system of quality assessment for disability services.

- Move swiftly to a person-centred approach to disability services, as agreed by the governments under the National Disability Agreement. Further extend services focusing on early intervention.

- Improve access to community-based residential health for people with mental health problems.

- Improve measurements of demand for disability services. Develop sound performance indicators.

\section{Addressing homelessness contributes to social inclusion}

- $\quad$ Continue efforts to reduce homelessness through a comprehensive policy focusing on early intervention and non-recurrence. Shift to a system of market rents and income-related rent-subsidies in public housing.

- Consider increasing the generosity of rent assistance by indexing it to the rent component of the CPI or to the market rates actually applied to dwellings occupied by income support recipients, provided that upward pressures on rents are contained, taking into account sustainability of fiscal policy. 
Improving the governance of policy action would contribute to raising participation and social inclusion

- Improve co-ordination among the various groups responsible for the delivery of services to people with multiple disadvantages. Engage the disadvantaged groups at an early stage of the policy process to adequately respond to their demand.

- $\quad$ Adopt an individualised approach to the provision of services for people with multiple disadvantages, in line to that adopted by the new employment services system. Services should cover the full range of needs of vulnerable people and be provided by a multi-disciplinary team.

- $\quad$ Further develop the comprehensive set of social inclusion indicators developed by the government. Proceed with plans to set up a framework to regularly measure and report on social inclusion outcomes.

\section{Bibliography}

ABS (Australian Bureau of Statistics) (2007), General Social Survey: Summary Results, Australia, 2006, Cat. No. 4159.0, ABS, Canberra, May.

ABS (2010a), Underemployed Workers, September 2009, Cat. No. 6265.0, ABS, Canberra, February.

ABS (2010b), Mental Health of Young People, 2007, Cat. No. 4840.0.55.001, ABS, Canberra, July.

ACOSS (Australian Council of Social Service) (2010), "Submission to the Independent Review of the Job Seeker Compliance Framework", July.

AIHW (Australian Institute of Health and Welfare) (2009), Australia's Welfare 2009, Australian Government, Canberra.

ASIB (Australian Social Inclusion Board) (2009), A Compendium of Social Inclusion Indicators: How is Australia Faring? Commonwealth of Australia, Canberra.

ASIB (2010), Social Inclusion in Australia: How Australia is Faring, Commonwealth of Australia, Canberra.

Atkinson, A. and A. Leigh, (2010), "The Distribution of Top Incomes in Australia", an update, http://www.apo.org.au/research/distribution-top-incomes-australia-updated

Australian Government (2008), "Developing a Disability Strategy for Australia: Access Inclusion Participation”, Discussion Paper for Consultation, October.

Australian Government (2009a), Universities, Innovation and Education Revolution, Commenwealth of Australia, Canberra, May.

Australian Government (2009b), Keep Australia Working, October, Canberra.

Australian Government (2010a), A Stronger, Fairer Australia, Commonwealth of Australia, Canberra.

Australian Government (2010b), Australia to 2050: Future Challenges, Commonwealth of Australia, Canberra. 
Australian Government (2010c), Population Flows: Immigration Aspects 2008-2009 Edition, Department of Immigration and Citizenship.

Australian Government (2010d), Australia's Future Tax System: Report to Treasurer December 2009, Commonwealth of Australia, Canberra.

Australian Government (2010e), Budget 2010-11, Commonwealth of Australia, Canberra, May.

Australian Government (2010f), "A National Health and Hospitals Network for Australia's Future”, Commonwealth of Australia, Canberra.

Bassanini, A., J. Rasmussen, and S. Scarpetta (1999), "The Economic Effects of Employment-Conditional Income Support Schemes for the Low-Paid", OECD Economics Department Working Papers, No. 224, OECD Publishing, Paris.

Boarini, R, Johansson, A., and M. Mira d'Ercole (2006) “Alternatives Measures of Well-Being," OECD Economic Department Working Papers, No. 476, OECD Publishers, Paris.

Breunig, R., and X. Gong (2010), "Child Care Availability, Quality and Affordability: Are Local Problems Related to Maternal Labour Supply?”, Treasury Working Paper, 2010-02, April, Canberra.

Breusch, J. (2010), "Health Equation is Incomplete", Australian Financial Review, 23 April.

Buddelmeyer, H., et al. (2006), "Evaluation of Policy Options to Encourage Welfare to Work", Melbourne Institute of Applied Economic and Social Research Working Paper, No. 9/06, University of Melbourne.

Buddelmeyer, H. and G. Kalb (2008), "The Effect of Minimum Wage Changes on Labour Supply and Distribution", in 2008 Minimum Wage Research Forum Proceedings, Vol. 2, Research Report, No. 4b/08, pp. 211-233, Australian FairPay Commission, Melbourne.

Causa, O., and C. Chapuis (2009), "Equity in Student Achievement Across OECD Countries: An Investigation of the Role of Policies", OECD Economics Department Working Papers, No. 708, OECD Publishing, Paris.

Causa, O., and A. Johansson (2009), "Intergenerational Social Mobility", OECD Economics Department Working Papers, No. 708, OECD Publishing, Paris.

Chamberlain, C., and D. MacKenzie (2008), Australian Census Analytic Program: Counting the Homeless, 2006, ABS cat. No. 2050.0, Australian Bureau of Statistics, Canberra.

COAG (Council of Australian Governments) (2006), National Action Plan on Mental Health 2006-2011, July.

COAG Reform Council (2010a), National Disability Agreement: Baseline Performance Report for 200809, COAG Reform Council, Sydney.

COAG Reform Council (2010b), National Affordable Housing Agreement: Baseline Performance Report for 2008-09, COAG Reform Council, Sydney.

COAG Reform Council (2010c), "COAG Reforms in the Spotlight", Medial Release, 4 June, COAG Reform Council, Sydney. 
Coumarelos, Z. Wei, and A. Zhou (2006), "Justice Made to Measure: NSW Legal Needs Survey in Disadvantaged Areas", Access to Justice and Legal Needs Vol. 3, Law and Justice Foundation of New South Wales, March.

Cowans, and D. Maclennan (2008), Visions for Social Housing, The Smith Institute.

Creedy, J. and G. Kalb (2005), "Behavioural Microsimulation Modelling for Tax Policy Analysis in Australia: Experience and Prospects", Melbourne Institute Working Paper Series, No. 2/05, Melbourne Institute of Applied Economic and Social Research, The University of Melbourne.

DEEWR (Department of Education, Employment and Workplace Relations) (2008), "Request for Tender for Employment Services 2009-12".

DEEWR (2010), “The 30 June 2010 Job Services Australia Star Rating”, http://www.deewr.gov.au/employment/jsa/performanceframework/pages/jsastarratings.aspx

DIG (Disability Investment Group) (2009), “The Way Forward: A New Disability Policy Framework for Australia", Report of the Disability Investment Group, Canberra, September.

Di Tella, R, MacCulloch, R., and A. J. Oswald (2003) “The Macroeconomics of Happiness”, Review of Economics and Statistics, 85, 809-827.

FaHCSIA (Australian Government Department of Families, Housing, Community Services and Indigenous Affairs) (2008), "The Road Home: A National Approach to Reducing Homelessness", White Paper, FaHCSIA, Canberra.

Ferre-i-Carbonnell, F. (2004), "How important is Methodology for the Estimates of the Determinants of Happiness?", Working Paper, University of Amsterdam.

Fitzpatrick, S. and M. Stephens (2007) "An International Review of Homelessness and Social Housing Policy”, Department of Communities and Local Governments, London.

Fleche, S., C., Smith, C. and P. Sorsa (2011), "Exploring Subjective Wellbeing Indicators in OECD Countries", OECD Economics Department Working Papers, OECD Publishing, Paris, forthcoming.

Gillard, J. (2010), “Creating Jobs and Skills in Australia”, Australian Labor Party, Jeffries Printing, Reversby.

Gong, X., R. Breunig, and A. King (2010), "How Responsive is Female Labour Supply to Child Care Costs - New Australian Estimates", Treasury Working Paper, 2010-03, Canberra, April.

Harding, A., Q.N Vu, A. Payne, and R. Percival (2009), "Trends in Effective Marginal Tax Rates in Australia from 1996-97 to 2006-07”, Economic Record, Vol. 85, Issue 271, pp. 449-461, December.

Healy, J. (2010), “The Minimum Wage Workforce in Australia: Extending the Evidence”, Working Paper, No. 162, National Institute of Labour Studies.

Heckman, J.J. and D.V. Masterov (2007), "The Productivity Argument for Investing in Young Children", NBER Working Paper, No. 13016, National Bureau of Economic Research, Cambridge, MA.

Helliwell, J.F et al. (2009), "International Evidence on the Social Context of Well-Being", NBER Working Paper, No. 14720, National Bureau of Economic Research, Cambrige, MA.

Helliwell, J.F., and C.P. Barrington-Leig. (2010), "Measuring and Understanding Subjective Well-Being", NBER Working Paper, No. 15887, National Bureau of Economic Research, Cambrige, MA. 
Homelessness Australia (2010), "Homelessness and over 55s", www.homelessness Australia.org.au.

Hoeckel, K. et al., (2008), Learning for Jobs: OECD Review of Vocational Education and Training Australia, OECD Publishing, Paris.

Immervoll, H., H. Kleven, C.T. Kreiner and E. Saez (2007), "Welfare Reform in Europe: A Microsimulation Analysis", Economic Journal, Vol. 117 (516), pp. 1-44.

Immervoll, H. and M. Pearson (2009), “A Good Time for Making Work Pay? Taking Stock of In-Work Benefits and Related Measures Across the OECD", OECD Social, Employment and Migration Papers, No. 81, OECD Publishing, Paris.

Immervoll, H. (2010), "Minimum-Income Benefits in OECD Countries: Policy Design, Effectiveness and Challenges", OECD Social, Employment and Migration Papers, No. 100, OECD Publishing, Paris.

James, R. et al. (2007), “Australian University Student Finances 2006: Final Report of a National Survey of Students in Public Universities", Universities Australia, August.

Johns, G. (2010), “Only Helping the Mentally Ill Will Halve Homelessness”, The Australian, 24 June.

Junankar, P.N (Raja) and S. Mahuteau (2005), "Do Migrants Get Good Jobs? New Migrant Settlement in Australia", The Economic Record, Vol. 81, No. 255, pp. S34-S46, August.

Kahneman, D. and A. Deaton (2010), "High Income Improves Evaluation of Life but not Emotional Wellbeing", PNAS Early Edition, Proceedings of the National Academy of Sciences.

Karmel, T. (2007), "Vocational education and Training Young People: Last but not Least", NCVER (National Centre for Vocational Education Research).

Karmel, T. and J. Misko (2009), “Apprenticeships and Traineeships in the Downturn”, NCVER.

Karmel, T., and P. Mlotkowski (2009), "The Impact of Wages on the Probability of Completing an Apprenticeship or Traineeship", NCVER.

Leigh, A. and C. Ryan (2008), "How and Why Has Teacher Quality Changed in Australia?", The Australian Economic Review, Vol. 41, No. 2, Blackwell Publishing, June.

Leigh, A. (2010), “Good Schools, Less Crime”, Australian Financial Review, 20 July.

Liebig, T. and S. Widmaier (2009), "Children of Immigrants in the Labour Markets of EU and OECD Countries: An Overview”, OECD Social, Employment and Migration Working Papers, No. 97, OECD Publishing.

Mavromaras, K., S. McGuinness, and M. Wooden (2007), "Overskilling in the Australian Labour Market", The Australian Economic Review, Vol. 40, pp. 307-312.

McKissack A., J. Chang, R. Ewing and J. Rahman (2008), "Structural Effects of a Sustained Rise in the Terms of Trade", Treasury Working Paper, 2008-01.

Nelms, L. and C. Tsingas (2010), "Literature Review on Social Inclusion and its Relationship or Minimum Wages and Workforce Participation", Fair Work Australia, February.

NHSC (National Housing Supply Council), (2010), 2nd State of Supply Report, Australian Government. 
NPWDACC (National People with Disabilities and Carer Council) (2009), "Shut Out: The Experience of People with Disabilities and their Families in Australia", National Disability Strategy Consultation Report, Australian Government.

OECD (2006), OECD Economic Surveys: Australia, No. 12, OECD Publishing, Paris.

OECD (2007a), Sickness, Disability and Work: Breaking the Barriers, Vol. 2: Australia, Luxemburg, Spain and the United Kingdom, OECD Publishing, Paris.

OECD (2007b), Employment Outlook, OECD Publishing, Paris.

OECD (2007c), Jobs for Immigrants, Vol. 1: Labour Market Integration in Australia, Denmark, Germany and Sweden, OECD Publishing, Paris.

OECD (2008a), OECD Economic Surveys: Australia, No. 18, OECD Publishing, Paris.

OECD (2008b), Economic Policy Reforms 2008: Going for Growth, OECD Publishing, Paris.

OECD (2010c), Education at a Glance, OECD Publishing, Paris.

OECD (2009a), Employment Outlook, OECD Publishing, Paris.

OECD (2009b), Health at a Glance 2009: OECD Indicators, OECD Publishing, Paris.

OECD (2010a), Employment Outlook, OECD Publishing, Paris.

OECD (2010b), OECD Economic Surveys: Luxembourg, No. 5, OECD Publishing, Paris

OECD (2010c), Education at a Glance, OECD Publishing, Paris.

Saunders, P. and Y. Naidoo (2009), "Poverty, Deprivation, and Consistent Poverty", Economic Record, Vol. 85, pp. 417-432, December.

SCRGSP (Steering Committee for the Review of Government Service Provision) (2009), Overcoming Indigenous Disadvantage: Key Indicators 2009, Steering Committee Report, Productivity Commission, Canberra.

SCRGSP (2010), Report on Government Services 2010, Steering Committee Report, Productivity Commission, Canberra.

Skills Australia (2010), Australian Workforce Futures: A national Development Strategy, Commonwealth of Australia.

Skulley, M. (2010), “Labour Puts IR Burden on Business”, Australian Financial Review, 14 April.

Stevenson, B., and J. Wolfers (2008) "Economic Growth and Subjective Well-Being: reassessing the Easterlin Paradox", NBER Working Paper.

Stiglitz, J.E., A. Sen and Fitoussi J-P. (2009), Report by the Commission on the Measurement of Economic Performance and Social Progress.

The Economist (2010), Economist debate: GDP, http://www.economist.com/debate/overview/171

Universities Australia (2008), “Advancing Equity and Participation in Australian Higher Education”, April. 
Venn, D. (2011), The Impact of Small-firm Exemptions from Employment Protection, OECD Social, Employment and Migration Working Paper, OECD Publishing, Paris, forthcoming.

Vinson, T. (2007), Dropping off the Edge: The Distribution of Disadvantage in Australia, Jesuit Social Service/Catholic Social Services, Richmond.

Vinson, T. (2009), "Jobless Families in Australia: Their Prevalence, Personal and Societal Costs, and Possible Policy Responses", Commonwealth of Australia.

Whiteford, P .(2009a), "Transfer Issues and Directions for Reform: Australian Transfer Policy in Comparative Perspective" Paper for Australia's Future Tax and Transfer Policy Conference, Department of the Treasury and Melbourne Institute of Applied Economic and Social Research, Melbourne 18-19 June, 2009.

Whiteford, P. (2009b), "Family Joblessness in Australia", a paper commissioned by the Social Inclusion Unit of the Prime Minister and Cabinet, January.

Winkelmann L., and R. Winkelmann (1998) "Why are the Unemployed So Unhappy? Evidence from Panel Data”, Economica, No. 65(257), pp. 1-15.

Wößmann, L. et al. (2007), "School Accountability, Autonomy, Choice, and the Level of Student Achievement: International Evidence from PISA 2003”, OECD Education Working Papers, No. 13, OECD Publishing, Paris. 


\section{Annex 1.A1}

1. To better understand what influences well-being in Australia, an ordered probit and Weighted Least Squares (WLS) regressions of self-reported life satisfaction were run for various explanatory variables with data from the World Values Survey. This method, which is in line with recent practice in the literature (Stevenson and Wolfers 2008), avoids the problems associated with arbitrary weights with indexbased comparisons. The ordered probit approach is justified by the qualitative categories scores defining the variable "life satisfaction", from 0 to 10 , and is the common theoretical approach in the literature. However, as both Ferrer-i-Carbonell and Frijters (2004) and Stevenson and Wolfers (2008) point out, in practice the choice of ordered probit or least squares make little difference for life satisfaction data. The WLS coefficients are then used as the basis for our analysis since they are relatively easy to interpret intuitively. The individual fixed effects (age, squared age, sex, marital status, number of children) included in the regression reduce the chance that unobserved heterogeneity, like ability, exaggeration or family background, is driving the observed correlation, making happiness data more comparable across individuals. Finally, the relative importance of well-being determinants is gauged through "compensating differentials", computed as the ratio of the WLS estimated coefficients of each determinant over log income, assorted with a statistical test which concludes on whether they are significant at $5 \%$ level or not.

Table 1.A1.1 Ordered probit regression of life satisfaction on different components

\begin{tabular}{|c|c|c|c|c|c|c|}
\hline & $\begin{array}{l}\text { Ordered } \\
\text { probit } \\
\text { regression, } \\
\text { micro data, } \\
\text { Australia }\end{array}$ & $\begin{array}{l}\text { WLS } \\
\text { regression, } \\
\text { micro data, } \\
\text { Australia }\end{array}$ & $\begin{array}{l}\text { Ordered } \\
\text { probit } \\
\text { regression, } \\
\text { micro data, } \\
\text { OECD } \\
\text { countries }\end{array}$ & $\begin{array}{l}\text { WLS } \\
\text { regression, } \\
\text { micro data, } \\
\text { OECD } \\
\text { countries }\end{array}$ & $\begin{array}{c}\text { Compensating } \\
\text { differentials } \\
\text { (with respect } \\
\text { to log income), } \\
\text { Australia }\end{array}$ & $\begin{array}{l}\text { Compensating } \\
\text { differentials } \\
\text { (with respect } \\
\text { to log income), } \\
\text { OECD }\end{array}$ \\
\hline \multicolumn{7}{|l|}{$\begin{array}{l}\text { Material living } \\
\text { standards }\end{array}$} \\
\hline Log income & $\begin{array}{l}0.130 * * \\
(0.054)\end{array}$ & $\begin{array}{l}0.219^{* *} \\
(0.074)\end{array}$ & $\begin{array}{l}0.105^{\star *} \\
(0.016)\end{array}$ & $\begin{array}{l}0.271^{\star *} \\
(0.013)\end{array}$ & -- & -- \\
\hline Wealth accumulation & $\begin{array}{l}0.029 * * \\
(0.011)\end{array}$ & $\begin{array}{l}0.036^{*} \\
(0.020) \\
\end{array}$ & $\begin{array}{l}0.040 * * \\
(0.003)\end{array}$ & $\begin{array}{l}0.083^{* *} \\
(0.003)\end{array}$ & $\begin{array}{l}0.16^{\star *} \\
(0.054)\end{array}$ & $\begin{array}{l}0.30^{* *} \\
(0.038)\end{array}$ \\
\hline \multicolumn{7}{|l|}{ Health } \\
\hline $\begin{array}{l}\text { State of health } \\
\text { (subjective) }\end{array}$ & $\begin{array}{l}0.341^{\star *} \\
(0.035)\end{array}$ & $\begin{array}{l}0.616^{* *} \\
(0.066)\end{array}$ & $\begin{array}{l}0.330^{\star \star} \\
(0.011)\end{array}$ & $\begin{array}{l}0.717^{* *} \\
(0.010)\end{array}$ & $\begin{array}{l}2.81^{* *} \\
(0.177)\end{array}$ & $\begin{array}{l}2.64^{\star \star} \\
(0.021)\end{array}$ \\
\hline \multicolumn{7}{|l|}{$\begin{array}{l}\text { Self-sufficiency and } \\
\text { education }\end{array}$} \\
\hline Unemployed & $\begin{array}{l}-0.250^{\star *} \\
(0.103)\end{array}$ & $\begin{array}{c}-0.485^{\star \star} \\
(0.184)\end{array}$ & $\begin{array}{l}-0.232^{* *} \\
(0.038)\end{array}$ & $\begin{array}{l}-0.582^{* \star} \\
(0.040)\end{array}$ & $\begin{array}{c}2.21 \\
(0.334)\end{array}$ & $\begin{array}{l}2.14^{\star *} \\
(0.081)\end{array}$ \\
\hline Educational level & $\begin{array}{l}0.057^{* *} \\
(0.016)\end{array}$ & $\begin{array}{l}0.044^{\star *} \\
(0.025)\end{array}$ & $\begin{array}{c}0.002 \\
(0.004)\end{array}$ & $\begin{array}{l}0.086^{\star *} \\
(0.003)\end{array}$ & $\begin{array}{c}0.20 \\
(0.68)\end{array}$ & $\begin{array}{l}0.31^{\star *} \\
(0.010)\end{array}$ \\
\hline \multicolumn{7}{|l|}{ Equity } \\
\hline $\begin{array}{l}\text { Income inequality } \\
\text { (perceived) }\end{array}$ & $\begin{array}{l}-0.004^{*} \\
(0.010)\end{array}$ & $\begin{array}{l}-0.009 \\
(0.018)\end{array}$ & $\begin{array}{l}-0.024^{\star \star} \\
(0.003)\end{array}$ & $\begin{array}{l}0.025^{\star *} \\
(0.002)\end{array}$ & $\begin{array}{c}0.04^{*} \\
(0.495)\end{array}$ & $\begin{array}{l}0.09^{* *} \\
(0.008)\end{array}$ \\
\hline \multicolumn{7}{|l|}{ Personal activities } \\
\hline $\begin{array}{l}\text { Freedom of choice and } \\
\text { control (subjective) }\end{array}$ & $\begin{array}{l}0.224^{* *} \\
(0.017)\end{array}$ & $\begin{array}{l}0.368^{* *} \\
(0.014)\end{array}$ & $\begin{array}{l}0.147^{* *} \\
(0.005)\end{array}$ & $\begin{array}{l}0.369^{* *} \\
(0.006)\end{array}$ & $\begin{array}{l}1.68^{* *} \\
(0.056)\end{array}$ & $\begin{array}{l}1.36^{* *} \\
(0.007)\end{array}$ \\
\hline
\end{tabular}


ECO/WKP(2011)21

\begin{tabular}{|c|c|c|c|c|c|c|}
\hline \multicolumn{7}{|l|}{ Environment } \\
\hline $\begin{array}{l}\text { C02 emissions } \\
\text { (national indicator) }\end{array}$ & $\begin{array}{l}-0.002^{* *} \\
(0.000)\end{array}$ & $\begin{array}{l}-0.003^{* *} \\
(0.000)\end{array}$ & $\begin{array}{l}-0.000 * * \\
(0.000)\end{array}$ & $\begin{array}{l}-0.000^{* *} \\
(0.000)\end{array}$ & $\begin{array}{c}0.01 \\
(0.104)\end{array}$ & $\begin{array}{c}0.000 \\
(0.006)\end{array}$ \\
\hline \multicolumn{7}{|l|}{ Social cohesion } \\
\hline $\begin{array}{l}\text { Trust in people } \\
\text { (subjective) }\end{array}$ & $\begin{array}{c}0.048 \\
(0.052)\end{array}$ & $\begin{array}{l}0.377^{* *} \\
(0.074)\end{array}$ & $\begin{array}{l}0.111^{* *} \\
(0.018)\end{array}$ & $\begin{array}{l}0.365^{\star *} \\
(0.027)\end{array}$ & $\begin{array}{l}1.72^{\star *} \\
(0.221)\end{array}$ & $\begin{array}{l}1.34^{* *} \\
(0.038)\end{array}$ \\
\hline Interest in politics & $\begin{array}{c}0.016 \\
(0.031)\end{array}$ & $\begin{array}{c}0.012 \\
(0.039)\end{array}$ & $\begin{array}{l}0.043^{\star *} \\
(0.010)\end{array}$ & $\begin{array}{l}0.034^{* *} \\
(0.014)\end{array}$ & $\begin{array}{c}0.05^{\star *} \\
(0.126)\end{array}$ & $\begin{array}{l}0.12^{* *} \\
(0.044)\end{array}$ \\
\hline $\begin{array}{l}\text { Extent of political } \\
\text { corruption (sobjective) }\end{array}$ & $\begin{array}{l}-0.123^{\star *} \\
(0.047)\end{array}$ & $\begin{array}{l}-0.076^{\star} \\
(0.063)\end{array}$ & $\begin{array}{l}-0.041^{* *} \\
(0.011)\end{array}$ & $\begin{array}{l}-0.193^{\star \star} \\
(0.016)\end{array}$ & $\begin{array}{l}0.34^{\star *} \\
(0.183)\end{array}$ & $\begin{array}{l}0.71^{\star *} \\
(0.046)\end{array}$ \\
\hline \multicolumn{7}{|l|}{ Individual fixed effects } \\
\hline Age & $\begin{array}{l}-0.060^{* *} \\
(0.010)\end{array}$ & $\begin{array}{l}-0.076^{\star *} \\
(0.011)\end{array}$ & $\begin{array}{c}-0.042^{* *} \\
(0.003)\end{array}$ & $\begin{array}{l}-0.093^{* *} \\
(0.002)\end{array}$ & -- & -- \\
\hline Squared age & $\begin{array}{l}0.072^{\star *} \\
(0.011)\end{array}$ & $\begin{array}{l}0.082^{\star \star} \\
(0.012)\end{array}$ & $\begin{array}{l}0.050^{\star *} \\
(0.003)\end{array}$ & $\begin{array}{l}0.099^{* *} \\
(0.002)\end{array}$ & -- & -- \\
\hline Sex & $\begin{array}{l}0.104^{*} \\
(0.051)\end{array}$ & $\begin{array}{l}0.065^{\star} \\
(0.053)\end{array}$ & $\begin{array}{l}0.069^{\star *} \\
(0.017)\end{array}$ & $\begin{array}{l}0.116^{* *} \\
(0.013)\end{array}$ & -- & -- \\
\hline Divorce & $\begin{array}{l}-0.117^{* *} \\
(0.015)\end{array}$ & $\begin{array}{c}-0.131^{* *} \\
(0.018)\end{array}$ & $\begin{array}{c}-0.065^{\star *} \\
(0.005)\end{array}$ & $\begin{array}{c}-0.109^{\star *} \\
(0.004)\end{array}$ & -- & -- \\
\hline Number of children & $\begin{array}{c}0.009 \\
(0.021)\end{array}$ & $\begin{array}{l}0.126^{\star *} \\
(0.032)\end{array}$ & $\begin{array}{l}0.022^{* *} \\
(0.006)\end{array}$ & $\begin{array}{l}0.013^{* *} \\
(0.005)\end{array}$ & -- & -- \\
\hline
\end{tabular}

Source: $\quad$ Data are from the World Values Survey, Australia and OECD countries, 1981 and 2007, 1660 respondents (Australia). Standard errors are in parentheses. And ${ }^{* *}$ means that this is significant at $5 \%$ level. * means this is significant at $10 \%$ level.

Notes: The dependant variable is the answer to the question: "In conclusion, we would like to ask you about your satisfaction with your life in general, please answer according to the following scale, 0 means completely dissatisfied and 10 means completely satisfied : how satisfied are you with your life, all things considered ?" The answers range on a scale from 0 , completely dissatisfied, to 10 , completely satisfied. The method used is ordered probit and WLS regressions of life satisfaction on components, with standard errors in parentheses, adjusted for individual-year fixed effects, for Australia, and individual-country-year fixed effects for OECD countries. The compensating differentials are the explanation power of each indicator for life satisfaction compared to log income. 


\section{WORKING PAPERS}

The full series of Economics Department Working Papers can be consulted at www.oecd.org/eco/workingpapers/

851 Meeting infrastructure needs in Australia

(March 2011) by Claude Giorno

850 Restoring fiscal sustainability in Spain

(March 2011) by Pierre Beynet, Andrés Fuentes, Robert Gillingham and Robert Hagemann

849. Drivers of homeownership rates in selected OECD countries

(March 2011) by Dan Andrews and Aida Caldera Sánchez

848. How efficient are banks in Hungary?

(February 2011) by Margit Molnár and Dániel Holló

847. Strengthening the macroeconomic policy framework in South Africa

(February 2011) by Tatiana Lysenko and Geoff Barnard

846. To move or not to move: what drives residential mobility rates in the OECD?

(February 2011) by Aida Caldera Sánchez and Dan Andrews

845. Reforming the labour market in Spain

(February 2011) by Anita Wölfl and Juan S. Mora-Sanguinetti

844. Macroeconomic Impact of Basel III

(February 2011) by Patrick Slovik and Boris Cournède

843. The policy and institutional drivers of economic growth across OECD and non-OECD economies: new evidence from growth regressions

by Romain Bouis, Romain Duval, and Fabrice Murtin

842. Limiting Long-Term Unemployment and Non-Participation in Sweden (February 2011) by Niels-Jakob Harbo Hansen

841. Enhancing the cost-effectiveness of climate change mitigation policies in Sweden (February 2011) by Stéphanie Jamet

840. Policies towards a sustainable use of water in Spain (February 2011) by Andrés Fuentes

839. Increasing public sector efficiency in Slovakia (January 2011) by Felix Hüfner

838. Raising education outcomes in Switzerland (January 2011) by Andrés Fuentes

837. The Price Responsiveness of Housing Supply in OECD Countries (January 2011) by Aida Caldera Sánchez and Åsa Johansson 
836. Housing markets and structural policies in OECD countries (January 2011) by Dan Andrews, Aida Caldera Sánchez and Åsa Johansson

835. Raising potential growth after the crisis: A quantitative assessment of the potential gains from various structural reforms in the OECD area and beyond (January 2011) by Romain Bouis and Romain Duval

834. The GDP impact of reform: a simple simulation framework (January 2011) by Sebastian Barnes, Romain Bouis, Philippe Briard, Sean Dougherty and Mehmet Eris

833. Improving the flexibility of the Dutch housing market to enhance labour mobility (January 2011) by Jens Høj

832. Making the Dutch pension system less vulnerable to financial crises (January 2011) by Jens Høj

831. Real house prices in OECD countries: the role of demand shocks and structural policy factors (December 2010) by Dan Andrews

830. International financial integration and the external positions of euro area countries (December 2010) by Philip R. Lane

829. Improving fiscal performance through fiscal councils (December 2010) by Robert Hagemann

828. Minimising risks from imbalances in European banking (December 2010) by Sebastian Barnes, Philip Lane and Artur Radziwill

827. Resolving and avoiding unsustainable imbalances (December 2010) by Sebastian Barnes

826. Current account imbalances in the euro area: a comparative perspective (December 2010) by Sebastian Barnes, Jeremy Lawson and Artur Radziwill

825. Does fiscal decentralisation strengthen social capital? Cross-country evidence and the experiences of Brazil and Indonesia (December 2010) by Luiz de Mello

824. Fiscal decentralisation and public investment: The experience of Latin America (December 2010) by Luiz de Mello 